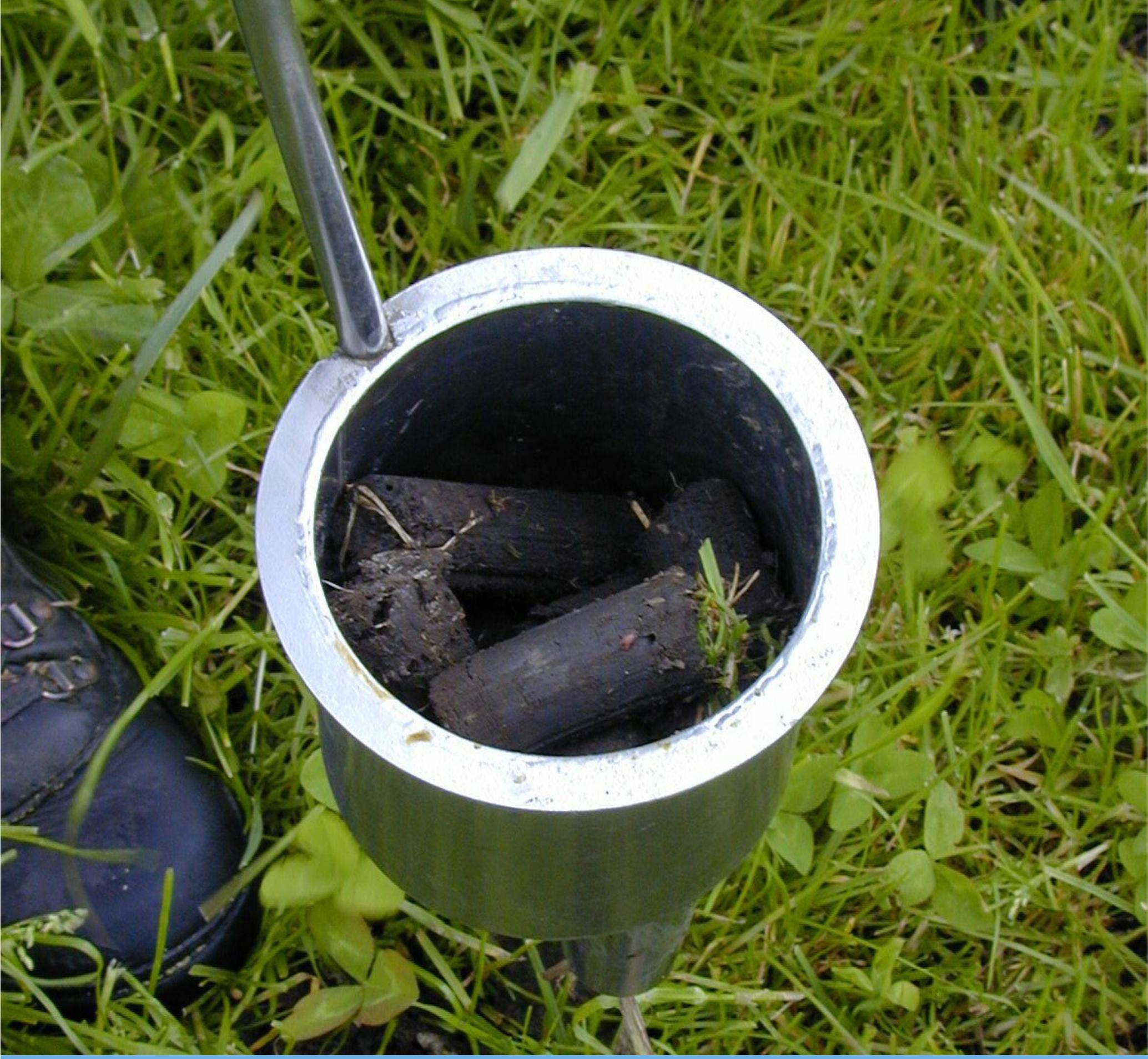

Aanwezigheid en dichtheden van plantparasitaire nematoden in Nederlands productiegrasland

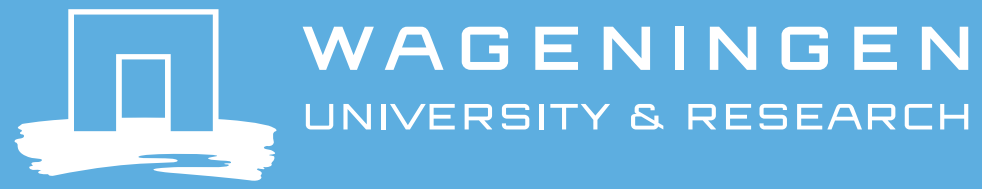





\section{Aanwezigheid en dichtheden van plantparasitaire nematoden in Nederlands productiegrasland}

Herman de Boer ${ }^{1)}$, Harm Keidel' ${ }^{2)}$ en Ton Schouten ${ }^{3)}$

1 Wageningen Livestock Research

2 LIOS, Zeewolde

3 RIVM, Bilthoven

Dit onderzoek is uitgevoerd door Wageningen Livestock Research, samen met LIOS en het RIVM, in opdracht van en gefinancierd door het Ministerie van Landbouw, Natuur en Voedselkwaliteit, binnen het Kennisbasisproject Bodemindicatoren (KB-21-002-010)

Wageningen Livestock Research

Wageningen, januari 2019 
De Boer, H.C, Keidel, H., Schouten, A.J., 2019. Aanwezigheid en dichtheden van plantparasitaire nematoden in Nederlands productiegrasland. Wageningen Livestock Research, Rapport 1155.

Dit rapport is gratis te downloaden op https://doi.org/10.18174/472296 of op www.wur.nl/livestock-research (onder Wageningen Livestock Research publicaties).

(C) 2016 Wageningen Livestock Research

Postbus 338, 6700 AH Wageningen, T 03174839 53, E info.livestockresearch@wur.nl, www.wur.nl/livestock-research. Wageningen Livestock Research is onderdeel van Wageningen University \& Research.

Wageningen Livestock Research aanvaardt geen aansprakelijkheid voor eventuele schade voortvloeiend uit het gebruik van de resultaten van dit onderzoek of de toepassing van de adviezen.

Alle rechten voorbehouden. Niets uit deze uitgave mag worden vermenigvuldigd en/of openbaar gemaakt worden door middel van druk, fotokopie, microfilm of op welke wijze dan ook zonder voorafgaande toestemming van de uitgever of auteur.

De certificering volgens ISO 9001 door DNV onderstreept ons kwaliteitsniveau. Op als onze onderzoeksopdrachten zijn de Algemene Voorwaarden van de Animal Sciences Group van DNS toepassing. Deze zijn gedeponeerd bij de Arrondissementsrechtbank Zwolle.

Wageningen Livestock Research Rapport 1155 


\section{Inhoud}

$\begin{array}{ll}\text { Woord vooraf } & 5\end{array}$

$\begin{array}{ll}\text { Samenvatting } & 7\end{array}$

1

$\begin{array}{lr}\text { Inleiding } & 9\end{array}$

2

$\begin{array}{ll}\text { Werkwijze } & 11\end{array}$

2.1 Herkomst gegevens 11

2.2 Bemonsterings- en extractiemethodiek 11

2.3 Gegevensselectie 12

$\begin{array}{lll}2.4 & \text { Analysemethodiek } & 15\end{array}$

3

$\begin{array}{ll}\text { Resultaten } & 17\end{array}$

$\begin{array}{lll}3.1 & \text { Aanwezige taxa } & 17\end{array}$

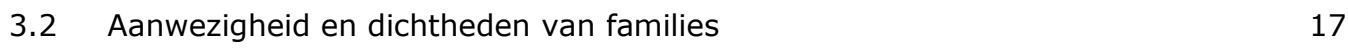

3.2.1 Familie Tylenchidae $\quad 20$

3.2.2 Familie Dolichodoridae $\quad 21$

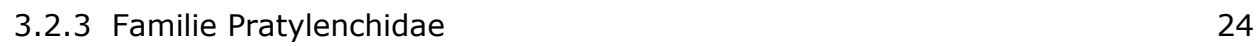

3.2.4 Familie Hoplolaimidae $\quad 26$

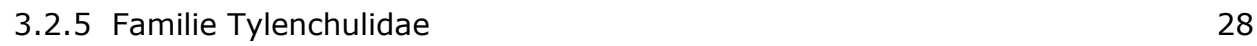

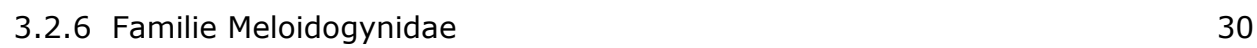

3.3 Gecorrigeerde dichtheden $\quad 32$

4 Discussie $\quad 33$

4.1 Methodiek 33

4.1.1 Representativiteit van de bemonstering 33

4.1.2 Bemonsterings- en extractiemethode 33

$\begin{array}{ll}4.1 .3 \text { Determinatie } & 34\end{array}$

4.2 Populatieveranderingen in de tijd $\quad 34$

$\begin{array}{lll}4.3 & \text { Schade } & 35\end{array}$

$5 \quad$ Reflectie en aanbevelingen $\quad 36$

$\begin{array}{ll}\text { Conclusies } & \mathbf{3 7}\end{array}$

$\begin{array}{ll}\text { Dankwoord } & 38\end{array}$

$\begin{array}{ll}\text { Literatuur } & 39\end{array}$

$\begin{array}{lll}\text { Bijlage } 1 & \text { Overzicht van aangetroffen herbivore taxa } & 40\end{array}$ 



\section{Woord vooraf}

Bodemgezondheid en bodemweerbaarheid zijn belangrijke thema's voor de Nederlandse landbouw. Bij deze thema's ligt het accent meestal op akkerbouwgewassen en veel minder op grasland, hoewel dit in Nederland een belangrijk gewas is. Bij de bodemgezondheid van grasland is de invloed van plantparasitaire nematoden op de productiviteit een belangrijk onderwerp. Hieraan is de laatste decennia echter weinig aandacht besteed. Daarom is binnen het Kennisbasis(KB)onderzoek van Wageningen UR besloten om dit onderwerp een nieuwe impuls te geven en de kennis op dit gebied te actualiseren. De impuls bestaat uit twee activiteiten: 1) een literatuurstudie naar de betekenis van plantparasitaire nematoden voor Nederlands productiegrasland en 2) een inventarisatie van de soorten en aantallen plantparasitaire nematoden die in Nederlands productiegrasland voorkomen. In dit rapport worden de resultaten van de inventarisatie beschreven. 


\section{Samenvatting}

Plantparasitaire nematoden (PPN) kunnen schade geven aan productiegrasland, wat tot uiting komt in een lagere opbrengst. Deze opbrengstderving is voor Nederland voor het verleden (1950-1980) geschat op jaarlijks gemiddeld 1,2 ton DS ha ${ }^{-1}$, wat nu overeenkomt met een economische schade van jaarlijks $€ 200$ miljoen. Een belangrijke eerste stap om inzicht te krijgen in welke soorten het meeste bijdragen aan de opbrengstderving is om een overzicht te krijgen van de soorten en aantallen herbivore nematoden die in Nederlands productiegrasland aanwezig zijn. Hiervoor is een dataset uit de BoBI-database van het RIVM (Bilthoven) geanalyseerd. De gebruikte gegevens zijn afkomstig van 417 melkveebedrijven op zand-, klei- en veengrond, waarbij per bedrijf het hele areaal grond is bemonsterd tot $10 \mathrm{~cm}$ diepte. In de mengmonsters van ieder bedrijf zijn onder andere de soorten en aantallen herbivore nematoden bepaald. Bij de analyse van de gegevens is het aantal taxa bepaald, de aanwezigheid en dichtheid van families en geslachten, en de aanwezigheid en dichtheid van de soorten in de vijf meest aangetroffen parasitaire geslachten. Van deze vijf geslachten is ook een frequentieverdeling van de dichtheid gemaakt.

Uit de resultaten blijkt dat in de geanalyseerde monsters 106 herbivore taxa aanwezig waren. Deze taxa konden worden ondergebracht in 14 families, 38 geslachten, en 61 soorten. De zes meest aangetroffen families waren de Tylenchidae (in 100\% van de monsters), Dolichodoridae (97\%), Pratylenchidae (91\%), Hoplolaimidae (87\%), Tylenchulidae (83\%), en Meloidogynidae (81\%). Minder vaak aangetroffen families waren de Heteroderidae (37\%), Trichodoridae (24\%), Longidoridae (15\%), en Criconematidae (8\%). De vijf meest aangetroffen parasitaire geslachten waren Pratylenchus (in $91 \%$ van alle monsters), Helicotylenchus (86\%), Paratylenchus (83\%), Meloidogyne (81\%), en Tylenchorhynchus (71\%). De gemiddelde dichtheden van deze geslachten waren respectievelijk 348 (Tylenchorhynchus), 221 (Pratylenchus), 248 (Helicotylenchus), 340 (Paratylenchus), en 270 (Meloidogyne) specimen $100 \mathrm{~g}^{-1}$ grond. Van deze dichtheden is de gemiddelde dichtheid van Pratylenchus en Meloidogyne onderschat vanwege het ontbreken van incubatieonderzoek. De gemiddelde dichtheid van Tylenchorhynchus is onderschat omdat een aanzienlijk deel van hun familie (Dolichodoridae) niet op geslacht gedetermineerd kon worden. Na een correctie hiervoor nam de gemiddelde dichtheid van Tylenchorhynchus toe van 348 tot 720 specimen $100 \mathrm{~g}^{-1}$ grond. Voor een aantal minder vaak aangetroffen families was de gebruikte bemonsterings- en extractiemethode niet optimaal, waardoor ook hun gemiddelde dichtheden onderschat kunnen zijn. Dit betreft de Heteroderidae, Trichodoridae, Longidoridae en Criconematidae.

Een vergelijking van de analyseresultaten met gegevens uit de periode 1950-1980 geeft de indruk dat de dichtheid van herbivore nematoden in productiegrasland over de laatste decennia is afgenomen. Ook de soortsamenstelling is waarschijnlijk veranderd; soorten die vroeger regelmatig voorkwamen (zoals Rotylenchus uniformis en Pratylenchus penetrans) werden in de huidige inventarisatie vrijwel niet aangetroffen. De voorliggende analyse maakt het voor de eerste keer mogelijk om voor Nederland een overzicht te geven van de aanwezigheid en minimale dichtheden van families, geslachten en soorten van herbivore en plantparasitaire nematoden in productiegrasland. Dit overzicht is voor een aantal taxa echter nog niet volledig vanwege een aantal beperkingen bij de monstername en -verwerking. Daarnaast is de gebruikte data gemiddeld 16 jaar oud. Veranderingen in het graslandmanagement sindsdien hebben waarschijnlijk geleid tot veranderingen in de soortsamenstelling en dichtheden. Om weer een actueel overzicht te krijgen is een nieuwe nationale kartering nodig. Doorgaande veranderingen in het graslandmanagement maken het noodzakelijk om een dergelijke kartering regelmatig te herhalen. Hierdoor kunnen veranderingen in de herbivore nematodenfauna worden gevolgd en kan desgewenst het graslandmanagement worden aangepast. De resultaten kunnen ook worden gebruikt om de bijdrage van herbivore nematoden aan biodiversiteit te monitoren. $\mathrm{Er}$ is daarom een nieuw nationaal systeem van monitoring nodig om een actueel beeld te krijgen en te houden van de aanwezigheid van herbivore en plantparasitaire nematoden in productiegrasland, van hun schade en van hun bijdrage aan biodiversiteit. 


\section{$1 \quad$ Inleiding}

Het effect van bodemgebonden ziekten en plagen op de opbrengst en kwaliteit van productiegrasland is in Nederland relatief onderbelicht. Bekend is dat onder andere insectenlarven (emelten, ritnaalden, engerlingen), schimmels (roest, meeldauw) en plantparasitaire nematoden schade kunnen veroorzaken. Aan deze ziekten en plagen wordt echter weinig aandacht besteed en er wordt weinig onderzoek naar verricht, zeker vergeleken met akkerbouwgewassen. Redenen daarvoor zijn dat, vergeleken met akkerbouwgewassen, de economische waarde van grasland relatief laag is, de weerbaarheid van grasland hoger wordt ingeschat en de schade in grasland minder duidelijk zichtbaar is. Grasland is echter wel een belangrijk gewas in Nederland en is met een areaal van 680.000 ha blijvend grasland en 248.000 ha tijdelijk grasland (CBS 2018) het meest geteelde gewas.

Een onderbelichte groep plaagorganismen, waarvan niet duidelijk is hoeveel schade ze momenteel in grasland aanrichten, zijn plantparasitaire nematoden (PPN). Dit zijn herbivore nematoden, kleine rondwormen die op en in de wortels leven en zich daarop voeden, en waarvan aangetoond is of verwacht wordt dat ze economische schade aan gewassen veroorzaken. Kort na de Tweede Wereldoorlog werd in Nederland aan dit type nematoden relatief veel onderzoek verricht door de afdeling Nematologie van de Plantenziektekundige Dienst (Wageningen), onder leiding van prof. Michiel Oostenbrink. Aanleiding daarvoor was de toen recente (her)ontdekking van schade door vrijlevende nematoden in de VS (Oostenbrink 1954, 1957b). Tot eind jaren zeventig is er in Nederland regelmatig (veld)onderzoek verricht naar schade door PPN in productiegrasland. Daarna is dit sterk afgenomen. Ondertussen zijn er in de laatste decennia, door schaalvergroting en intensivering van de melkveehouderij, grote veranderingen geweest in het graslandmanagement. Deze veranderingen bestaan uit onder meer uit toegenomen ruilverkaveling, verbeterde ontwatering en afwatering, een hogere frequentie van herinzaai, meer monocultuur van Engels raaigras, veranderingen in bemesting, gebruik van zwaardere machines en een afname van beweiden ten gunste van maaien. Dergelijke veranderingen hebben niet alleen effect gehad op de botanische samenstelling en productiviteit van grasland, maar (daarmee) ook op de diversiteit en aantallen van PPN, en op de mogelijke schade die ze veroorzaken.

Door de geschetste veranderingen is het in toenemende mate van belang geworden om, op basis van de huidige stand van het onderzoek, te inventariseren wat de belangrijkste effecten van PPN zijn op het functioneren van Nederlands productiegrasland. Vragen daarbij zijn: welke soorten nematoden komen voor en in welke aantallen? Welke soorten veroorzaken schade, hoe veroorzaken ze schade, onder welke omstandigheden, en is deze schade relevant? Hebben parasitaire nematoden ook positieve effecten? En in hoeverre kunnen positieve effecten de negatieve effecten compenseren? Kunnen parasitaire nematoden ook bestreden worden? Om deze vragen te beantwoorden is een literatuurstudie uitgevoerd (De Boer 2018).

Een belangrijke conclusie uit deze studie is dat PPN in het verleden (1950-1980) verantwoordelijk waren voor een opbrengstderving van gemiddeld 1,2 ton DS ha-1 jaar $^{-1}$ of $13 \%$ van de opbrengst van Nederlands productiegrasland (De Boer 2018). Dit komt overeen met een economisch relevante schade van jaarlijks $€ 200$ miljoen (De Boer 2018). Door veranderingen in het graslandmanagement sinds de periode 1950-1980 kunnen er ook veranderingen geweest zijn in de aanwezige soorten en aantallen PPN, en daardoor in het niveau van opbrengstderving. Het is niet bekend welke soorten PPN momenteel in welke aantallen aanwezig zijn in productiegrasland. Daardoor is ook niet duidelijk welke soort(en) het meest (kunnen) bijdragen aan de opbrengstderving. Een eerste stap om dit inzicht te verkrijgen is het uitvoeren van een nationale kartering van herbivore nematoden in productiegrasland. Een dergelijke kartering is in Nederland niet eerder uitgevoerd.

Wel zijn door het RIVM (Bilthoven) in de periode 1993 t/m 2014 algemene karteringen gemaakt van de verspreiding van bodemorganismen in Nederland, inclusief herbivore nematoden. Het doel van deze karteringen was het ontwikkelen van een BodemBiologische Indicator (BoBI) en de resultaten 
zijn vastgelegd in de zogenoemde BoBI-database. Om een indruk te krijgen van de meer recente aanwezigheid en dichtheden van herbivore en plantparasitaire nematoden in Nederlands

productiegrasland, zijn de gegevens van herbivore nematoden in deze database geanalyseerd. Van deze analyse en de resultaten wordt verslag gedaan in dit rapport. 


\section{Werkwijze}

\section{$2.1 \quad$ Herkomst gegevens}

De analyse van de aanwezigheid en dichtheden van PPN in Nederlands productiegrasland is uitgevoerd met gegevens uit de BoBI-database. Deze database bevat de resultaten van 22 jaar (1993 t/m 2014) bodemmonitoring en wordt beheerd door het RIVM (Bilthoven). Een beschrijving van de achtergronden en aanpak van het BoBI-project is gegeven door Schouten et al. (2002) en Rutgers et al. (2007). Tijdens de monitoringsperiode zijn een groot aantal percelen onder verschillende vormen van beheer onderzocht, waaronder graslanden gebruikt voor de melkveehouderij. Deze graslanden lagen op verschillende grondsoorten en verspreid over heel Nederland.

\subsection{Bemonsterings- en extractiemethodiek}

Voor een goede interpretatie van de resultaten uit de BoBI-database wordt de destijds gevolgde bemonsterings- en extractiemethodiek kort beschreven en voorzien van een aantal opmerkingen:

- De monsters uit het reguliere onderzoek zijn niet op perceelsniveau, maar bedrijfsbreed genomen. Er is dus per bedrijf een verzamelmonster gemaakt van alle percelen (Schouten et al. 2002);

- De monsters zijn genomen met een graslandboor $(\varnothing 2,3 \mathrm{~cm})$ tot $10 \mathrm{~cm}$ diepte;

- De soorten en aantallen nematoden zijn t/m 2013 bepaald door het Bedrijfslaboratorium voor grond en gewasonderzoek (Blgg, Oosterbeek; nu Eurofins Agro) en in 2014 door LIOS (Zeewolde). De nematoden zijn via een speciale zeef- en spoelmethode (Oostenbrinktrechter gecombineerd met wattenfilter) uit de grond gehaald. Hiervoor is steeds $100 \mathrm{ml}$ grond gebruikt, waarvan ook het gewicht werd bepaald. Het organische materiaal in het monster werd niet apart geïncubeerd. De levende nematoden werden geconcentreerd en gevangen met behulp van een zeef (voor de grote exemplaren) en wattenfilter. De nematoden kropen hier actief doorheen gedurende drie dagen en werden daarna verzameld in een kleine hoeveelheid water. Het totale aantal nematoden per $100 \mathrm{~g}$ grond werd geschat door twee keer $10 \%$ van de geëxtraheerde nematoden te tellen. Na de telling werd het monster gefixeerd en werden preparaten gemaakt om ca. 150 nematoden onder een lichtmicroscoop te identificeren. De gebruikte methode komt overeen met de NEN-norm (NEN 2011);

- Een deel van de 150 nematoden per preparaat bestond uit jonge, niet volledig ontwikkelde nematoden (juvenielen) en soms ook uit beschadigde nematoden. Deze nematoden konden niet altijd op geslacht en/of soort worden gedetermineerd. Bij de resultaten wordt daarom weergegeven welk percentage van de nematoden op geslacht of soort gedetermineerd kon worden;

- Er is geen specifiek onderzoek gedaan naar de cysten (vrouwtjes) van de familie Heteroderidae (cystenaaltjes). De aanwezige vrijlevende larven (stadium J2) en mannetjes zijn wel geteld maar niet verder gedetermineerd. Het niet uitvoeren van cystenonderzoek kan er de reden van zijn dat bepaalde soorten cystenaaltjes niet zijn gevonden; Fleming et al. (2016) vond de geslachten Punctodera en Globodera alleen als cysten;

- Er is geen apart wortelonderzoek (met incubatie) gedaan voor de families Meloidogynidae en Pratylenchidae (die deels in de wortels aanwezig zijn). De aangetroffen vrijlevende exemplaren zijn geteld en gedetermineerd;

- $\mathrm{Er}$ is geen specifiek onderzoek gedaan naar de familie Trichodoridae. Nematoden van deze familie zijn zeer mobiel en komen vaak dieper in de grond voor dan nematoden van andere families. Aangetroffen exemplaren zijn wel gedetermineerd;

- $\mathrm{Er}$ is geen specifiek onderzoek gedaan naar de familie Longidoridae. Dit zijn opvallend grote nematoden en bij specifiek onderzoek wordt dieper bemonsterd en worden grotere monsters met een hogere opstroomsnelheid verwerkt. Dit laatste is bij BoBI opgevangen door gebruik te maken van de combi-opspoelmethode (H. Keidel, pers. med.); 
- Er is geen specifiek onderzoek gedaan naar de familie Criconematidae. Door gebruik van de combiopspoelmethode werden echter wel nematoden van deze familie gevangen en deze exemplaren zijn gedetermineerd;

- Er is geen specifiek onderzoek gedaan naar de familie Anguinidae (galvormende nematoden). Vooral het geslacht Anguina kan bij grassen galvorming geven en is daardoor schadelijk;

- Er is geen specifiek onderzoek gedaan naar stengelaaltjes (Ditylenchus) of bladaaltjes; (Aphelenchoides). Gevonden exemplaren van Aphelenchoides zijn in de database aangemeld als fungivore nematoden en daardoor bij de analyse buiten beschouwing gebleven. Echte bladaaltjes worden overigens in grasland niet aangetroffen;

- Bij de families waarvoor specifiek onderzoek nodig is, dat tijdens de BoBI-monitoring niet werd uitgevoerd, is de kans groot dat de gevonden aantallen onderschattingen zijn van de werkelijk aanwezige aantallen;

- In de BoBI-database zijn de aantallen nematoden weergegeven per $100 \mathrm{~g}$ verse grond. In het reguliere onderzoek voor de land- en tuinbouw worden de aantallen vermeld per $100 \mathrm{ml}$ of per 250 $\mathrm{ml}$ grond. Om deze resultaten onderling te kunnen vergelijken, moeten dichtheden eerst worden omgerekend van gewicht naar volume, of andersom.

\subsection{Gegevensselectie}

Voorafgaande aan de analyse werd een gegevensselectie uitgevoerd. Als eerste stap werden alle biologische parameters, behalve de nematodengegevens, verwijderd uit een kopie van de oorspronkelijke BoBI-database. Alle andere informatie, bijvoorbeeld over locaties en grondgebruik, bleef aanwezig. In de BoBI-database staan in totaal 428 nematodentaxa. Deze zijn verdeeld over verschillende niveaus, zoals families, geslachten en soorten. Ten behoeve van de huidige analyse zijn de gegevens verder opgeschoond door alleen de taxa aan te houden waarvan bekend is dat ze op planten kunnen voeden. Hiervan waren er 141 aanwezig. Deze taxa werden gecontroleerd op geldigheid en alle niet-erkende taxa werden verwijderd. De volgende aanpassingen werden gedaan:

- Meloidogyne heterodera is geen geldige soort en werd verwijderd;

- Psilenchidae is een synoniem van de geldige benaming Tylenchidae; de naam werd daarom aangepast en Psilenchidae werd als taxon verwijderd;

- Paratylenchidae is een synoniem van de geldige benaming Tylenchulidae; de naam werd daarom aangepast en Paratylenchidae werd als taxon verwijderd.

Na de controle op geldigheid werden de overgebleven 139 taxa ingedeeld naar voedingswijze volgens Yeates et al. (1993) (Bijlage 1). De volgende voedingswijzen werden daarbij onderscheiden:

- 1a) Sedentaire endoparasieten. Dit zijn soorten die het grootste deel van hun levenscyclus vastzitten aan de wortels. Een voorbeeld zijn de vrouwtjes van de familie Heteroderidae en van het geslacht Meloidogyne;

- 1b) Migrerende endoparasieten. Dit zijn relatief mobiele soorten die zowel binnen als buiten de wortels worden aangetroffen. Een voorbeeld is de familie Pratylenchidae;

- 1c) Semi-endoparasieten. Deze soorten komen normaal buiten de plant voor, maar dringen soms de wortels binnen. Een voorbeeld is de familie Hoplolaimidae;

- 1d) Ectoparasieten. Deze nematoden blijven buiten de wortels. Ze voeden zich door het aanprikken van wortels met hun stekel of stilet. Voorbeelden zijn de families Dolichodoridae, Criconematidae, Hemicycliophoridae, Tylenchulidae, Trichodoridae en Longidoridae;

- 1e) Epidermale cel- en haarwortelvoeders. Deze nematoden blijven ook buiten de wortels en hebben een relatief fijne stekel waarmee ze niet diep in de wortels kunnen dringen. Daarom worden ze meestal niet als parasitair gezien. De belangrijkste familie is Tylenchidae.

In de BoBI-database zijn de resultaten van 1331 monsters onderverdeeld in de volgende categorieën:

- Bodemgebruik: agrarisch, half natuur, natuur, industrie, slibdepot, stadspark, wonen;

- Vegetatie: akkerbouwgewassen, bloembollen, bos, fruit, gras, halfnatuurlijk grasland, heide, klaver, vollegronds groenten;

- Grondsoort: dalgrond, gerijpt slib, lemig zand, löss, rivierklei, strooisel, veen, zand, zand+veen, zeeklei;

- Bedrijfstype: akkerbouw, gemengd bedrijf, melkveehouderij, tuinbouw, n.v.t. (o.a. proefvelden); 
- Bedrijfssysteem: biologisch, gangbaar, gangbaar extensief, gangbaar intensief, gangbaar intensief+.

De resultaten van de monsters met de aanduiding 'Vegetatie Gras' $(n=725)$ werden geselecteerd voor verdere analyse. De verdeling van deze monsters over verschillende gebruikscategorieën en grondsoorten is gegeven in Tabel 1. De verschillen in bedrijfsvoering tussen de vijf categorieën binnen 'Bedrijfstype Melkveehouderij' is onvoldoende duidelijk. De aanduiding 'Gangbaar' is destijds vooral gemaakt om het onderscheid met 'Biologisch' aan te geven. In het Landelijk Meetnet Bodemkwaliteit (LMB) werd onderscheid gemaakt tussen melkveebedrijven met een lage veedichtheid (extensief), een hoge veedichtheid (intensief), en met een intensieve neventak (intensief + ). Het laatste type bedrijven bestond vooral uit kleinere varkenshouderijen of pluimveehouderijen (in combinatie met melkkoeien) met een groter aandeel maïsland. De grens tussen extensief en intensief lag bij 2,8 GVE/ha. De zes monsters met aanduiding 'Melkveehouderij Gangbaar' op zandgrond (Tabel 1) komen uit het LMB 4; dit zijn de laatste twee jaren van de opvolger van BoBI, het Bodem Ecosysteemdiensten Onderzoek (BEO). In het LMB 4 is geen opdeling meer gemaakt in 'Gangbaar', 'Gangbaar Extensief' en 'Gangbaar Intensief'.

Tabel 1 Verdeling van de geselecteerde monsters met aanduiding 'Vegetatie Gras' over gebruikscategorieën en grondsoorten.

\begin{tabular}{|c|c|c|c|c|c|c|c|c|c|}
\hline \multirow[t]{2}{*}{ Gebruik } & \multicolumn{9}{|c|}{ Grondsoort } \\
\hline & Zand & $\begin{array}{l}\text { Lemig } \\
\text { zand }\end{array}$ & Zeeklei & Zavel & Rivierklei & Löss & Veen & $\begin{array}{l}\text { Zand+ } \\
\text { veen }\end{array}$ & Totaal \\
\hline Halfnatuurlijk grasland & 13 & 0 & 0 & 0 & 0 & 0 & 0 & 4 & 17 \\
\hline Melkveehouderij Biologisch & 65 & 0 & 22 & 0 & 9 & 4 & 15 & 0 & 115 \\
\hline Melkveehouderij Gangbaar & 6 & 0 & 62 & 3 & 54 & 7 & 100 & 0 & 232 \\
\hline Melkveehouderij Gangbaar extensief & 106 & 0 & 0 & 0 & 0 & 0 & 0 & 0 & 106 \\
\hline Natuur & 0 & 0 & 0 & 0 & 0 & 0 & 20 & 0 & 20 \\
\hline Proefboerderij De Marke & 13 & 0 & 0 & 0 & 0 & 0 & 0 & 0 & 13 \\
\hline Proefveld Bakel & 44 & 0 & 0 & 0 & 0 & 0 & 0 & 0 & 44 \\
\hline Proefveld Bovenbuurt (Wageningen) & 6 & 0 & 0 & 0 & 0 & 0 & 0 & 0 & 6 \\
\hline Stadsparken gras & 13 & 0 & 1 & 0 & 0 & 0 & 0 & 0 & 14 \\
\hline Totaal & 371 & 43 & 85 & 3 & 73 & 11 & 135 & 4 & 725 \\
\hline
\end{tabular}

In de subset van 725 monsters zijn de monsters van de categorieën 'Halfnatuurlijk grasland', 'Natuur', en 'Stadsparken gras' niet representatief voor productiegrasland en daarom niet meegenomen voor de analyse. De monsters met aanduiding 'Proef' waren niet genomen op bedrijfsniveau, maar op proefvelden of plots binnen proefvelden. Deze monsters zijn vanwege de afwijkende manier van bemonsteren niet meegenomen. Er bleef hierdoor een subset van 558 monsters over. In deze subset waren nog enkele kleinere subsets aanwezig, waarbij niet bedrijfsbreed was bemonsterd. Ook deze monsters zijn niet meegenomen voor de analyse. Hierdoor bleven er 431 monsters over met bedrijfsbrede bemonstering.

Als vervolgstap zijn op de bovenstaande set monsters nog de volgende aanpassingen gedaan:

- Alle monsters met aanduiding 'Gangbaar' zijn samengebracht tot één categorie 'Gangbaar'. Hierdoor waren er twee hoofdcategorieën bedrijfsvoering: 'Biologisch' en 'Gangbaar';

- De grondsoorten zijn ondergebracht in drie hoofdcategorieën: zand, klei en veen. De groep 'klei' is de samenvoeging van rivierklei en zeeklei. De monsters van 'zavel' en 'löss' zijn vanwege het afwijkende karakter van deze grondsoorten en de geringe aantallen $(n=14)$ niet meegenomen.

De overblijvende set monsters $(n=417)$ is gebruikt voor de verdere analyse. Een overzicht van de verdeling van deze monsters over type bedrijfsvoering en grondsoort staat in Tabel 2, een overzicht van de monsternamelocaties op de kaart van Nederland staat in Figuur 1, en een overzicht van het aantal monsters per jaar van monstername staat in Figuur 2. Een 'gemiddeld jaar van monstername' 
werd berekend door per jaar van monstername het aantal monsters als fractie van totale aantal monsters te vermenigvuldigen met het jaartal, en de uitkomsten van alle jaren te sommeren.

Tabel 2 Verdeling van de gebruikte set monsters $(n=417)$ over type bedrijfsvoering en grondsoort.

\begin{tabular}{|c|c|c|c|c|}
\hline \multirow[t]{2}{*}{ Bedrijfsvoering } & \multicolumn{4}{|c|}{ Grondsoort } \\
\hline & Zand & Klei & Veen & Alles \\
\hline Biologisch & 36 & 31 & 15 & 82 \\
\hline Gangbaar & 169 & 116 & 50 & 335 \\
\hline Totaal & 205 & 147 & 65 & 417 \\
\hline
\end{tabular}

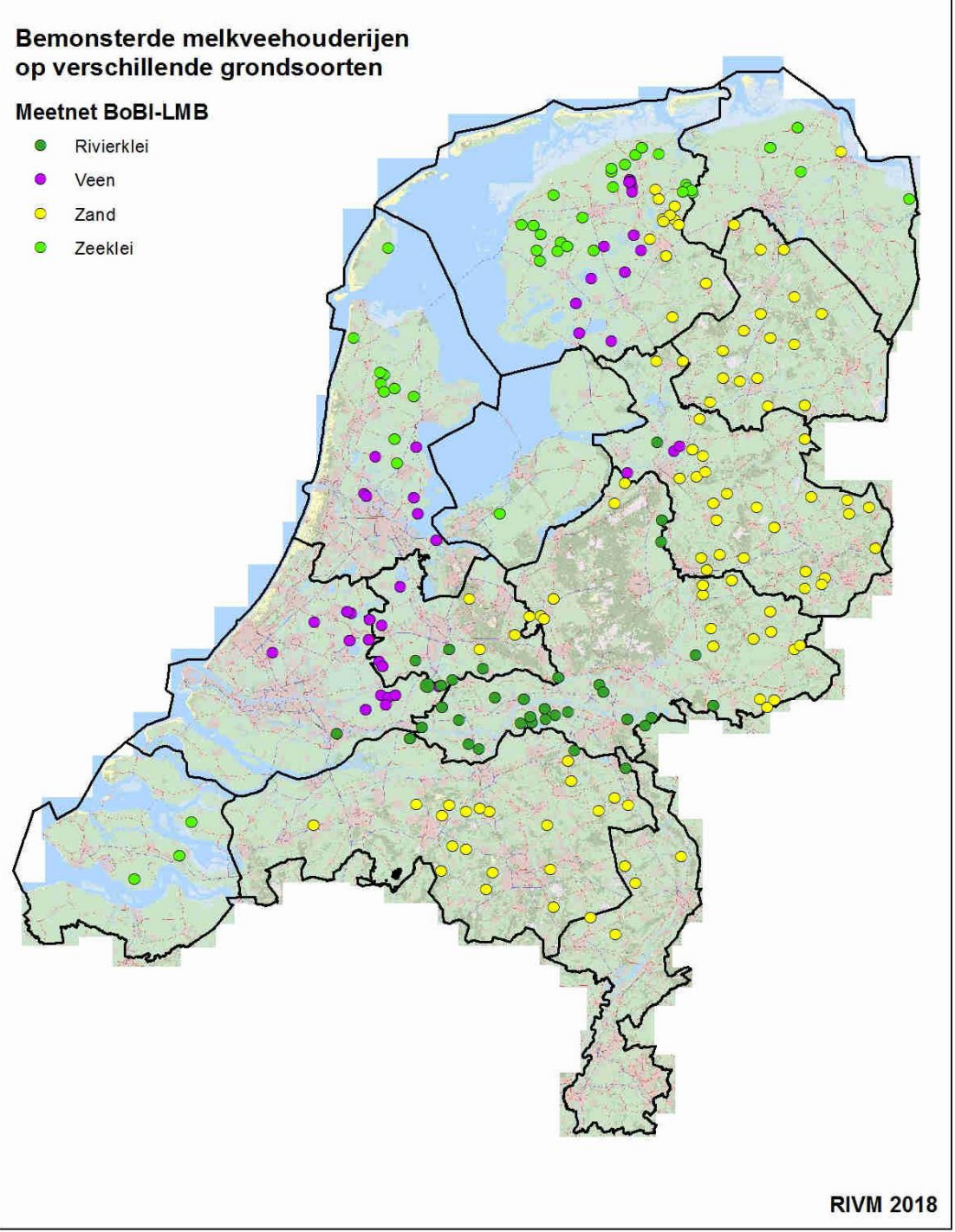

Figuur 1 Overzicht van de locaties van bemonsterde melkveebedrijven $(n=417)$ op de kaart van Nederland, per grondsoort. 


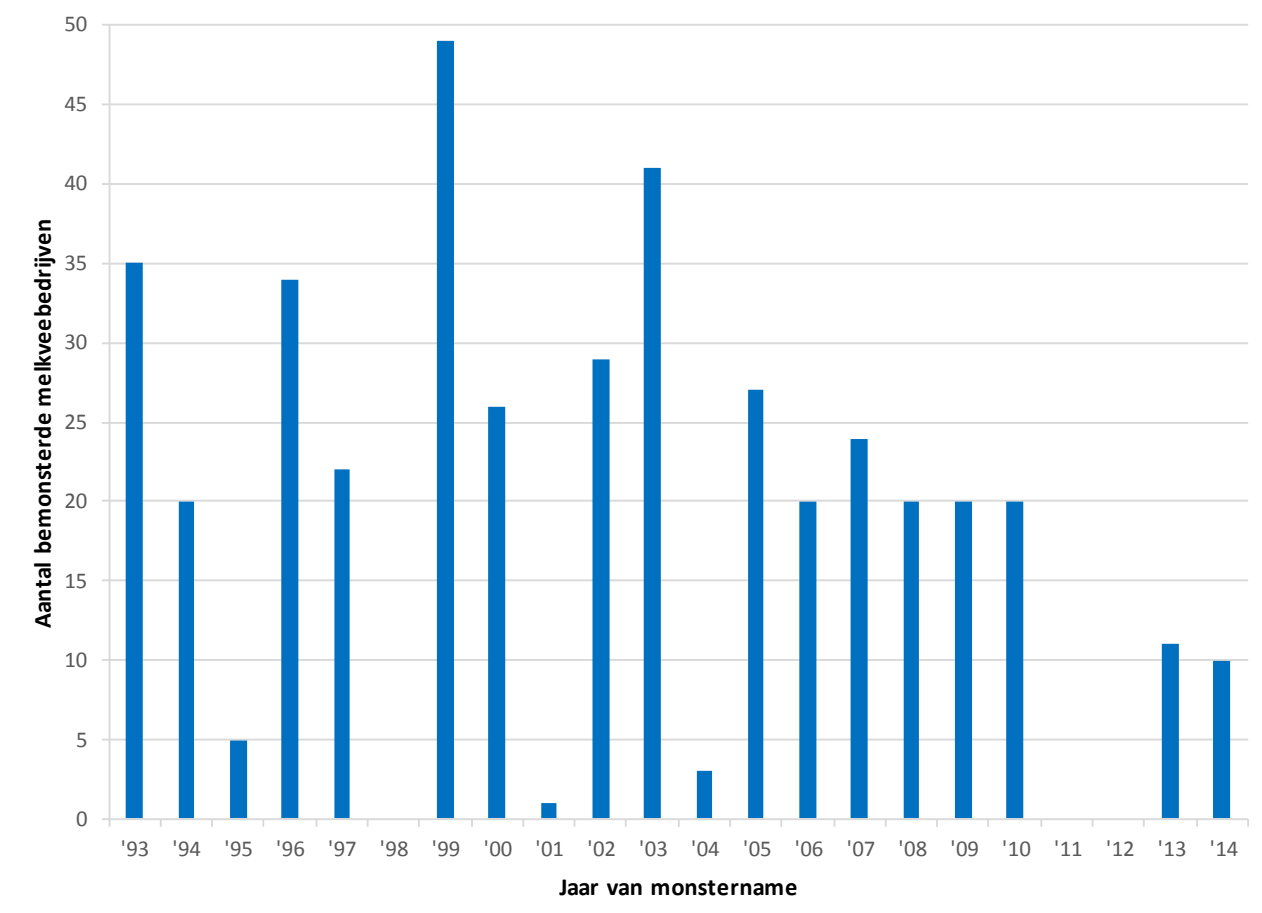

Figuur 2 Verdeling van de bemonsterde melkveebedrijven ( $n=417)$ over de monitoringsperiode (1993 t/m 2014).

\subsection{Analysemethodiek}

De analyse startte met het tellen van het totale aantal (facultatieve) herbivore taxa die in de BoBIdatabase werden aangetroffen in alle monsters met aanduiding 'Vegetatie Gras' $(n=725)$ en in de uiteindelijk gebruikte dataset $(n=417)$. Het aantal taxa geeft een beeld van de (bio)diversiteit die de herbivore nematoden vertegenwoordigen. Bij de laatste telling werd éénmalig onderscheid gemaakt tussen monsters van bedrijven met biologische bedrijfsvoering en van bedrijven met gangbare bedrijfsvoering. Dit onderscheid is daarna niet meer gemaakt, omdat de huidige analyse zich niet focust op het vaststellen van eventuele verschillen tussen deze typen bedrijfsvoering. De in de eindset aangetroffen herbivore taxa werden vervolgens ondergebracht in families, geslachten en soorten. Per familie werd de aanwezigheid en de gemiddelde dichtheid in alle monsters berekend. Vervolgens werd de totale gemiddelde dichtheid van herbivore nematoden berekend (alle families opgeteld). Met behulp van de gemiddelde dichtheden per familie werden vervolgens de aandelen van de verschillende families, en van de voedingswijzen (Yeates et al. 1993), in de totale gemiddelde dichtheid berekend.

Vervolgens werd voor de zes meest aangetroffen families per aangetroffen geslacht berekend in welk deel van alle monsters dit geslacht aanwezig was, evenals de gemiddelde dichtheid in de betreffende monsters. De aanwezigheid van een familie en de bijbehorende geslachten, en de gemiddelde dichtheden, geven een indruk van het belang van de betreffende taxa. De meest aangetroffen familie werd niet verder geanalyseerd dan op geslachtsniveau, omdat deze familie niet als parasitair bekend staat. De vijf andere meest aangetroffen families, die allen parasitaire geslachten bevatten, werden verder geanalyseerd. Voor het meest aangetroffen (parasitaire) geslacht werd voor de monsters waarin dit geslacht voorkwam de aanwezigheid en de gemiddelde dichtheid van iedere aangetroffen soort berekend. Deze analyse geeft inzicht in het belang van specifieke geslachten binnen families en van soorten binnen geslachten.

Bij een aantal families en/of geslachten kon een aanzienlijk deel van de nematoden niet op geslacht en/of soort gedetermineerd worden. De belangrijkste reden hiervoor was dat het juveniele exemplaren betrof, waarvan de geslachts- of soortkenmerken onvoldoende duidelijk vastgesteld konden worden. Omdat de niet-gedetermineerde exemplaren niet meetellen bij de dichtheid van een geslacht, kan dit leiden tot een onderschatting. Daarom is voor de vijf meest aangetroffen geslachten aanvullend een 
correctie op de berekende dichtheid uitgevoerd, waarbij werd aangenomen dat het aandeel van een geslacht in de niet-gedetermineerde nematoden gelijk was aan het aandeel in de gedetermineerde nematoden.

Tenslotte werd bij de vijf families voor het meest aangetroffen geslacht een frequentieverdeling gemaakt van de (ongecorrigeerde) dichtheden in alle monsters $(n=417)$, verdeeld over dichtheidsklassen van 200 specimen per klasse. Deze klassebreedte werd gekozen om zo voor alle vijf geslachten een voldoende gedetailleerde frequentieverdeling te kunnen geven. De frequentieverdelingen zijn potentieel bruikbaar om een beeld te krijgen van welk deel van het graslandareaal mogelijk problemen van een bepaald geslacht of soort ondervindt. Alle bovenstaande berekeningen werden zowel gedaan per grondsoort als voor alle grondsoorten samen. 


\subsection{Aanwezige taxa}

In alle monsters met aanduiding 'Vegetatie Gras' in de BoBI-database $(n=725)$ werden in totaal 138 verschillende (facultatieve) herbivore taxa gevonden. In de uiteindelijke gekozen set van bedrijfsbreed genomen monsters $(n=417)$ waren 106 verschillende (facultatieve) herbivore taxa aanwezig. Hiervan konden 61 taxa tot op soortniveau gedetermineerd worden, 35 alleen tot op geslachtsniveau en 10 alleen tot op familieniveau (Bijlage 1 ). In de monsters van bedrijven met biologische bedrijfsvoering werden minder taxa aangetroffen dan in de monsters van bedrijven met gangbare bedrijfsvoering, en in de veenmonsters minder dan in de klei- of zandmonsters (Tabel 3). Hierbij wordt aangetekend dat er veel meer monsters genomen zijn van gangbare dan van biologische bedrijven; bij een groter bemonsterd oppervlak worden in theorie ook meer taxa aangetroffen. Omdat de focus van de huidige analyse niet ligt op het vaststellen van eventuele verschillen tussen bedrijfstypen, wordt het onderscheid tussen gangbaar en biologisch in de verdere analyse niet meer gemaakt.

Tabel 3 Aantal aanwezige taxa $(n=106)$ van (facultatieve) herbivore nematoden in de geanalyseerde BoBI-dataset ( $n=417)$, opgesplitst per type bedrijfsvoering en grondsoort.

\begin{tabular}{|c|c|c|c|c|}
\hline Bedrijfsvoering & \multicolumn{4}{|c|}{ Grondsoort } \\
\hline Gangbaar & 78 & 46 & 70 & 100 \\
\hline Alle & 82 & 47 & 77 & 106 \\
\hline
\end{tabular}

\subsection{Aanwezigheid en dichtheden van families}

\section{Aanwezigheid}

De 106 taxa konden worden ondergebracht in 14 families en daarbinnen in 38 geslachten. De meest aangetroffen families waren (Tabel 4):

1. Tylenchidae: in $100 \%$ van de monsters. Deze familie bestaat uit epidermale cel- en haarwortelvoeders (1e) en wordt niet als parasitair gezien;

2. Dolichodoridae: in $97 \%$ van de monsters. Deze familie bestaat uit ectoparasieten (1d);

3. Pratylenchidae: in $91 \%$ van de monsters. Deze familie bestaat uit migrerende endoparasieten (1b);

4. Hoplolaimidae: in $87 \%$ van de monsters. Deze familie bestaat uit semi-endoparasieten (1c);

5. Tylenchulidae: in $83 \%$ van de monsters. Deze familie bestaat uit ectoparasieten (1d);

6. Meloidogynidae: in $81 \%$ van de monsters. Deze familie bestaat uit sedentaire endoparasieten (1a).

Er werden verder regelmatig vertegenwoordigers uit drie andere belangrijke plantparasitaire families gevonden. Omdat voor deze families de onderzoeksmethodiek niet optimaal was, worden ze hierna niet verder geanalyseerd op geslachten en soorten. De families zijn:

7. Heteroderidae: in $37 \%$ van de monsters. Deze familie bestaat uit sedentaire endoparasieten (1a). De in de BoBI-dataset gevonden exemplaren betreffen alleen juvenielen (J2) of mannetjes welke niet op soort gedetermineerd konden worden;

8. Trichodoridae: in $24 \%$ van de monsters. Deze familie bestaat uit ectoparasieten (1d);

9. Longidoridae: in $15 \%$ van de monsters. Deze familie bestaat uit ectoparasieten (1d).

Drie andere families waren duidelijk minder algemeen dan de voorgaande negen: 
10. Criconematidae: in $5 \%$ van de monsters. Deze familie bestaat uit ectoparasieten (1d) en wordt vooral onder houtachtige gewassen gevonden;

11. Nordiidae: in $6 \%$ van de monsters. Soorten zijn overwegend carnivoor of omnivoor. Een aantal soorten is mogelijk (facultatief) herbivoor (Yeates et al. 1993) en zijn dan ectoparasieten (1d);

12. Hemicycliophoridae: in $3 \%$ van de monsters. Deze familie bestaat uit ectoparasieten (1d).

Tot slot zijn twee van de aangetroffen 14 families maar in enkele monsters gevonden, vaak in zeer lage aantallen. Het gaat hierbij om families die geen (economische) schade geven:

13. Belondiridae: in $0,2 \%$ van de monsters. Het betreft soorten die overwegend carnivoor of omnivoor zijn. Een aantal soorten is mogelijk (facultatief) planteneter (Yeates et al. 1993);

14. Ecphyadophoridae: in $0,2 \%$ van de monsters. Dit zijn zeldzaam voorkomende, haardunne nematoden.

Samengevat waren alle plantparasitaire families, behalve de familie Anguinidae, in de monsters aanwezig. De familie Anguinidae bestaat vooral uit schimmeleters. Voor het vaststellen van de aanwezigheid van het parasitaire geslacht Anguina is specifiek onderzoek nodig. Dit werd binnen BoBI niet uitgevoerd.

Tabel 4 Aandeel (\%) van alle monsters $(n=417)$ waarin de 14 aangetroffen families aanwezig waren, per grondsoort en voor alle grondsoorten samen.

\begin{tabular}{|c|c|c|c|c|}
\hline \multirow[t]{2}{*}{ Familie } & \multicolumn{4}{|c|}{ Grondsoort } \\
\hline & Zand & Klei & Veen & Alle \\
\hline & $(205)^{1)}$ & $(147)$ & $(65)$ & (417) \\
\hline Tylenchidae & 100 & 100 & 100 & 100 \\
\hline Pratylenchidae & 87 & 94 & 98 & 91 \\
\hline Hoplolaimidae & 80 & 95 & 95 & 87 \\
\hline Heteroderidae & 36 & 35 & 46 & 37 \\
\hline Trichodoridae & 43 & 6 & 2 & 24 \\
\hline Longidoridae & 22 & 9 & 8 & 15 \\
\hline Criconematidae & 0 & 18 & 8 & 8 \\
\hline Nordiidae & 7 & 3 & 6 & 6 \\
\hline
\end{tabular}

\section{Dichtheden}

In alle monsters kwamen gemiddeld 2457 herbivore nematoden per $100 \mathrm{~g}$ grond voor (Tabel 5). Het gemiddelde aantal was het hoogst in veengrond en het laagst in zandgrond. Van de zes meest aangetroffen families had Tylenchidae de hoogste gemiddelde totale dichtheid (in alle monsters), gevolgd door Dolichodoridae, Tylenchulidae, Hoplolaimidae, Meloidogynidae, en Pratylenchidae (Tabel 5 , Figuur 3). De zes meest talrijke families vertegenwoordigden $97 \%$ van de gemiddelde totale dichtheid in alle monsters. De dichtheden van de families Trichodoridae en Longidoridae waren laag, wat mede veroorzaakt kan zijn door de bemonsteringsmethodiek (Paragraaf 2.2). Opgedeeld naar de vijf voedingswijzen kan $36 \%$ van de gemiddelde dichtheid van herbivore nematoden geclassificeerd worden als niet-parasitair en de overige 64\% als plantparasieten met verschillende schadelijkheid (Figuur 4). NB: de gemiddelde dichtheid van een familie in de monsters waarin deze familie voorkwam kan berekend worden door de gemiddelde dichtheid in Tabel 5 te delen door het percentage aanwezigheid in Tabel 4. 
Tabel 5 Gemiddelde dichtheid (\# $100 \mathrm{~g}^{-1}$ grond) van de aangetroffen families in alle monsters $(n=417)$, per familie en in totaal, per grondsoort en voor alle grondsoorten samen.

\begin{tabular}{|c|c|c|c|c|}
\hline \multirow[t]{2}{*}{ Familie } & \multicolumn{4}{|c|}{ Grondsoort } \\
\hline & Zand & Klei & Veen & Alle \\
\hline & $(205)^{1)}$ & (147) & $(65)$ & (417) \\
\hline Tylenchidae & 582 & 1164 & 1165 & 878 \\
\hline Dolichodoridae & 627 & 440 & 616 & 560 \\
\hline Tylenchulidae & 264 & 217 & 487 & 282 \\
\hline Hoplolaimidae & 156 & 306 & 325 & 235 \\
\hline Heteroderidae & 35 & 40 & 77 & 43 \\
\hline Trichodoridae & 29 & 2 & 1 & 15 \\
\hline Longidoridae & 12 & 3 & 2 & 7 \\
\hline Criconematidae & 0 & 14 & 4 & 6 \\
\hline Alle families & 1977 & 2673 & 3485 & 2457 \\
\hline
\end{tabular}

1) Totale aantal monsters

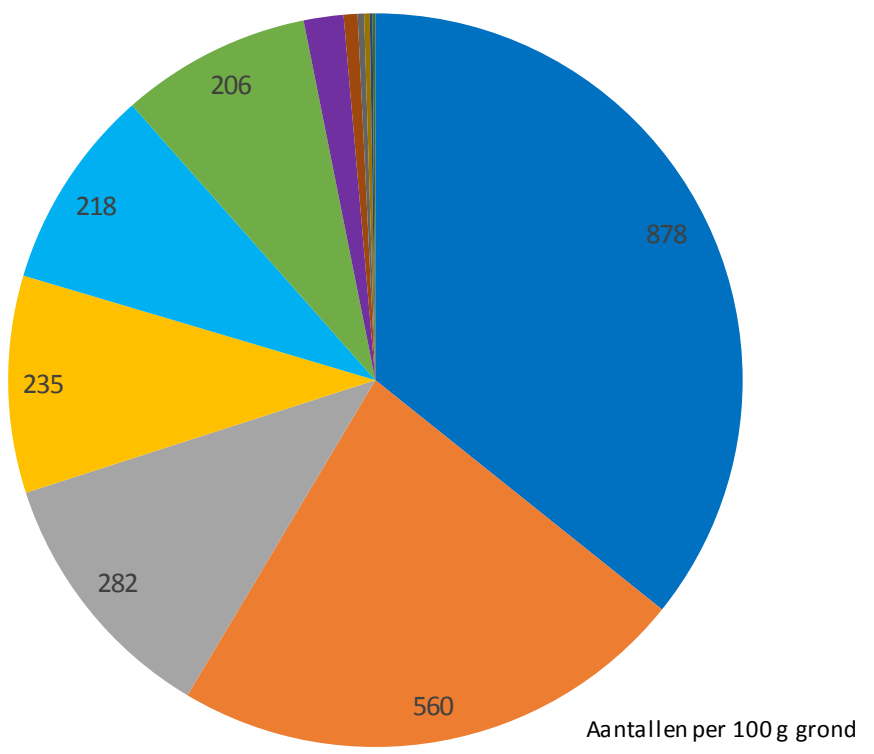

- Tylenchidae

Dolichodoridae

- Tylenchulidae

- Hoplolaimidae

- Meloidogynidae

- Pratylenchidae

- Heteroderidae

- Trichodoridae

- Longidoridae

- Criconematidae

- Hemicycliophoridae

- Nordiidae

Belondiridae

- Ecphyadophoridae

Figuur 3 Gemiddelde dichtheden (\#100 g $\mathrm{g}^{-1}$ ) en het aandeel van families in het totale aantal herbivore nematoden op de bemonsterde melkveebedrijven. 


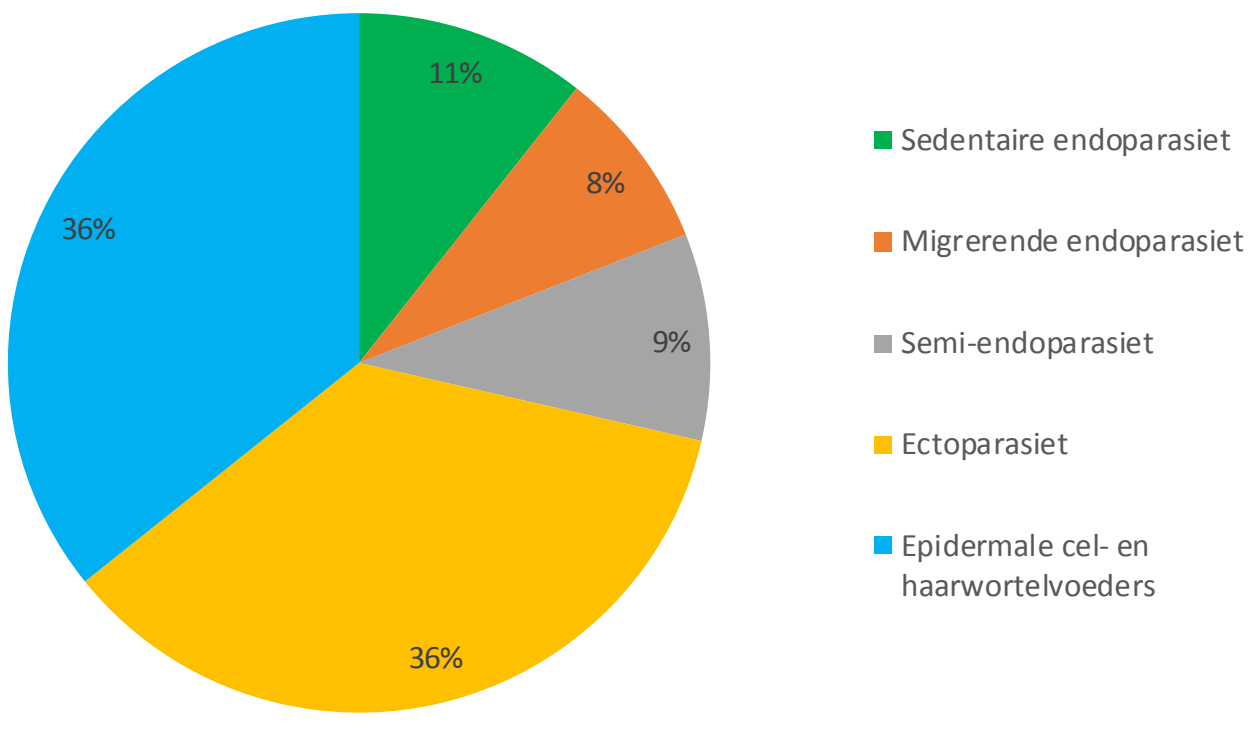

Figuur 4 Aandeel (\%) van de vijf voedingswijzen (naar Yeates et al. 1993) in het totale gemiddelde aantal herbivore nematoden op de bemonsterde melkveebedrijven.

\subsubsection{Familie Tylenchidae}

\section{Aanwezigheid}

Van de families werd Tylenchidae het meest aangetroffen, in 416 van de 417 monsters (100\%) (Tabel $6)$. Een groot deel (94\%) van de monsters bevatte Tylenchidae die niet op geslacht gedetermineerd konden worden ('Tylenchidae sp.'). Van de 10 gevonden geslachten waren Filenchus (44\%) en Aglenchus (37\%) het meest algemeen, gevolgd door Malenchus (30\%), Psilenchus (18\%) en Coslenchus (14\%). De geslachten Filenchus en Malenchus werden op klei- en veengrond vaker aangetroffen dan op zandgrond, terwijl bij Aglenchus er weinig verschil was tussen de grondsoorten.

Tabel 6 Aanwezigheid (\%) van de familie Tylenchidae en bijbehorende geslachten in alle geanalyseerde monsters $(n=417)$, per grondsoort en voor alle grondsoorten samen.

\begin{tabular}{|c|c|c|c|c|}
\hline \multirow[t]{2}{*}{ Familie } & \multicolumn{4}{|c|}{ Grondsoort } \\
\hline & Zand & Klei & Veen & Alle \\
\hline Tylenchidae & 100 & 100 & 100 & 100 \\
\hline Tylenchidae sp. $^{1)}$ & 99 & 89 & 88 & 94 \\
\hline Filenchus & 26 & 63 & 62 & 44 \\
\hline Psilenchus & 2 & 42 & 12 & 18 \\
\hline Coslenchus & 17 & 12 & 8 & 14 \\
\hline Tylenchus & 0 & 18 & 5 & 7 \\
\hline Boleodorus & 0 & 11 & 0 & 4 \\
\hline Lelenchus & 1 & 1 & 0 & 1 \\
\hline
\end{tabular}

1) niet op geslacht te determineren 


\section{Dichtheden}

In de monsters waarin Tylenchidae voorkwam waren van deze familie gemiddeld 880 nematoden 100 $\mathrm{g}^{-1}$ grond aanwezig (Tabel 7). Van dit aantal kon 75\% niet op geslacht gedetermineerd worden. Van het gemiddelde totale aantal gedetermineerde nematoden (219 $100 \mathrm{~g}^{-1}$ grond, ex. Tylenchidae sp.) (Tabel 7) was 45\% van het geslacht Filenchus, $22 \%$ van het geslacht Aglenchus, 19\% van het geslacht Malenchus, en was de overige $14 \%$ afkomstig van de andere aangetroffen geslachten.

Tabel 7 Gemiddelde dichtheden (\# $100 \mathrm{~g}^{-1}$ grond) van de familie Tylenchidae en bijbehorende geslachten in de monsters waarin Tylenchidae voorkwam $(n=416)$, per grondsoort en voor alle grondsoorten samen.

\begin{tabular}{|c|c|c|c|c|}
\hline \multirow[t]{2}{*}{ Taxon } & \multicolumn{4}{|c|}{ Grondsoort } \\
\hline & Zand & Klei & Veen & Alle \\
\hline Tylenchidae & 585 & 1164 & 1165 & 880 \\
\hline Tylenchidae sp. ${ }^{1)}$ & 471 & 843 & 844 & 661 \\
\hline Filenchus & 30 & 159 & 184 & 99 \\
\hline Psilenchus & 2 & 31 & 12 & 14 \\
\hline Coslenchus & 11 & 6 & 5 & 8 \\
\hline Tylenchus & 0 & 10 & 2 & 4 \\
\hline Boleodorus & 0 & 9 & 0 & 3 \\
\hline
\end{tabular}

1) niet op geslacht te determineren

\subsubsection{Familie Dolichodoridae}

\section{Aanwezigheid}

De familie Dolichodoridae werd na Tylenchidae het meest aangetroffen, in 405 van de 417 monsters (97\%) (Tabel 8). Een groot deel (78\%) van de monsters bevatte Dolichodoridae die niet op geslacht gedetermineerd konden worden ('Dolichodoridae sp.'). Van de 11 gevonden geslachten kwam het geslacht Tylenchorhynchus in $71 \%$ van de monsters voor en was daarmee het meest algemeen, op grote afstand gevolgd door Dolichorhynchus (12\%). Het geslacht Tylenchorhynchus werd op alle grondsoorten in vergelijkbare mate aangetroffen, terwijl Dolichorhynchus op klei- en veengrond vaker werd aangetroffen dan op zandgrond. De negen andere geslachten werden gemiddeld slechts beperkt aangetroffen. 
Tabel 8 Aanwezigheid (\%) van de familie Dolichodoridae en bijbehorende geslachten in alle geanalyseerde monsters $(n=417)$, per grondsoort en voor alle grondsoorten samen.

\begin{tabular}{|c|c|c|c|c|}
\hline \multirow[t]{2}{*}{ Familie } & \multicolumn{4}{|c|}{ Grondsoort } \\
\hline & Zand & Klei & Veen & Alle \\
\hline Dolichodoridae & 99 & 95 & 97 & 97 \\
\hline Dolichodoridae sp. ${ }^{1)}$ & 80 & 73 & 80 & 78 \\
\hline Tylenchorhynchus & 71 & 71 & 72 & 71 \\
\hline Scutylenchus & 0 & 10 & 0 & 3 \\
\hline Bitylenchus & 0 & 4 & 9 & 3 \\
\hline Merlinius & 0 & 5 & 3 & 2 \\
\hline Trophurus & 0 & 6 & 0 & 2 \\
\hline Quinisulcius & 1 & 2 & 5 & 2 \\
\hline
\end{tabular}

1) niet op geslacht te determineren

Een verdere uitwerking voor het meest algemene geslacht Tylenchorhynchus op soortniveau laat zien dat in meer dan de helft van alle monsters er soorten aanwezig waren die niet gedetermineerd konden worden ('Tylenchorhynchus sp.') (Tabel 9). Van de vier gedetermineerde soorten kwam T. dubius in $59 \%$ van de monsters voor en $T$. maximus in $17 \%$ van de monsters; $T$. bryobius en $T$. striatus kwamen vrijwel niet voor. De soort T. maximus kwam in de zandmonsters vaker voor dan in de kleien veenmonsters.

Tabel 9 Aanwezigheid (\%) van (gedetermineerde) Tylenchorhynchus soorten in alle geanalyseerde monsters $(n=417)$, per grondsoort en voor alle grondsoorten samen.

\begin{tabular}{|c|c|c|c|c|}
\hline \multirow[t]{2}{*}{ Soort } & \multicolumn{4}{|c|}{ Grondsoort } \\
\hline & Zand & Klei & Veen & Alle \\
\hline T. sp. & 52 & 63 & 66 & 58 \\
\hline T. dubius & 60 & 56 & 62 & 59 \\
\hline T. maximus & 32 & 3 & 3 & 17 \\
\hline T. striatus & 0 & 1 & 0 & 0 \\
\hline T. bryobius & 0 & 0 & 0 & 0 \\
\hline
\end{tabular}

1) niet op soort te determineren

\section{Dichtheden}

In de monsters waarin Dolichodoridae voorkwam waren van deze familie in totaal gemiddeld 576 nematoden $100 \mathrm{~g}^{-1}$ grond aanwezig (Tabel 10). Van dit aantal kon $48 \%$ op geslacht gedetermineerd worden. Van het gemiddelde totale aantal gedetermineerde nematoden (278 $100 \mathrm{~g}^{-1} \mathrm{grond}$, ex. Dolichodoridae sp.) (Tabel 10) was 91\% van het geslacht Tylenchorhynchus. 
Tabel 10 Gemiddelde dichtheden (\# $100 \mathrm{~g}^{-1}$ grond) van de familie Dolichodoridae en bijbehorende geslachten in de monsters waarin Dolichodoridae voorkwam $(n=405)$, per grondsoort en voor alle grondsoorten samen.

\begin{tabular}{|c|c|c|c|c|}
\hline \multirow[t]{2}{*}{ Taxon } & \multicolumn{4}{|c|}{ Grondsoort } \\
\hline & Zand & Klei & Veen & Alle \\
\hline Dolichodoridae sp. ${ }^{1)}$ & 434 & 151 & 186 & 298 \\
\hline Tylenchorhynchus & 196 & 266 & 408 & 253 \\
\hline Dolichorhynchus & 3 & 22 & 26 & 13 \\
\hline Scutylenchus & 0 & 10 & 0 & 4 \\
\hline Bitylenchus & 0 & 7 & 7 & 3 \\
\hline Merlinius & 0 & 2 & 2 & 1 \\
\hline Nagelus & 0 & 1 & 0 & 1 \\
\hline Quinisulcius & 0 & 1 & 5 & 1 \\
\hline Trophurus & 0 & 4 & 0 & 1 \\
\hline Geocenamus & 0 & 1 & 0 & 0 \\
\hline Macrotrophurus & 0 & 0 & 0 & 0 \\
\hline Paratrophurus & 0 & 0 & 0 & 0 \\
\hline
\end{tabular}

1) niet op geslacht te determineren

Van het gemiddelde totale aantal nematoden van het geslacht Tylenchorhynchus kon 36\% op soort gedetermineerd worden (Tabel 11 ). Hiervan was $85 \%$ van de soort $T$. dubius en de overige $15 \%$ van de soort T. maximus. De gemiddelde dichtheid van T. maximus was op zandgrond hoger dan op kleiof veengrond.

Tabel 11 Gemiddelde dichtheden (\# $100 \mathrm{~g}^{-1}$ grond) van het geslacht Tylenchorhynchus en bijbehorende soorten in de monsters waarin Tylenchorhynchus voorkwam $(n=295)$, per grondsoort en voor alle grondsoorten samen.

\begin{tabular}{lllll} 
Taxon & Grondsoort & & Veen & Alle \\
\hline & Zand & Klei & & \\
\hline Tylenchorhynchus & 277 & 356 & 547 & \\
\hline T. sp ${ }^{1)}$ & & & & \\
\hline$T$. dubius & 146 & 242 & 411 & 222 \\
\hline$T$. maximus & 96 & 111 & 133 & 107 \\
\hline$T$. bryobius & 33 & 2 & 4 & 18 \\
\hline$T$. striatus & 1 & 0 & 0 & 0 \\
\hline
\end{tabular}

1) niet op soort te determineren

Frequentieverdeling dichtheid van Tylenchorhynchus

De frequentieverdeling van de dichtheid van het geslacht Tylenchorhynchus is gegeven in Figuur 5. Het geslacht was, afhankelijk van grondsoort, in $28 \%$ (veen) tot $30 \%$ (zand) van alle monsters afwezig (of kon niet gedetermineerd worden) (Klasse 0 in Figuur 5). 


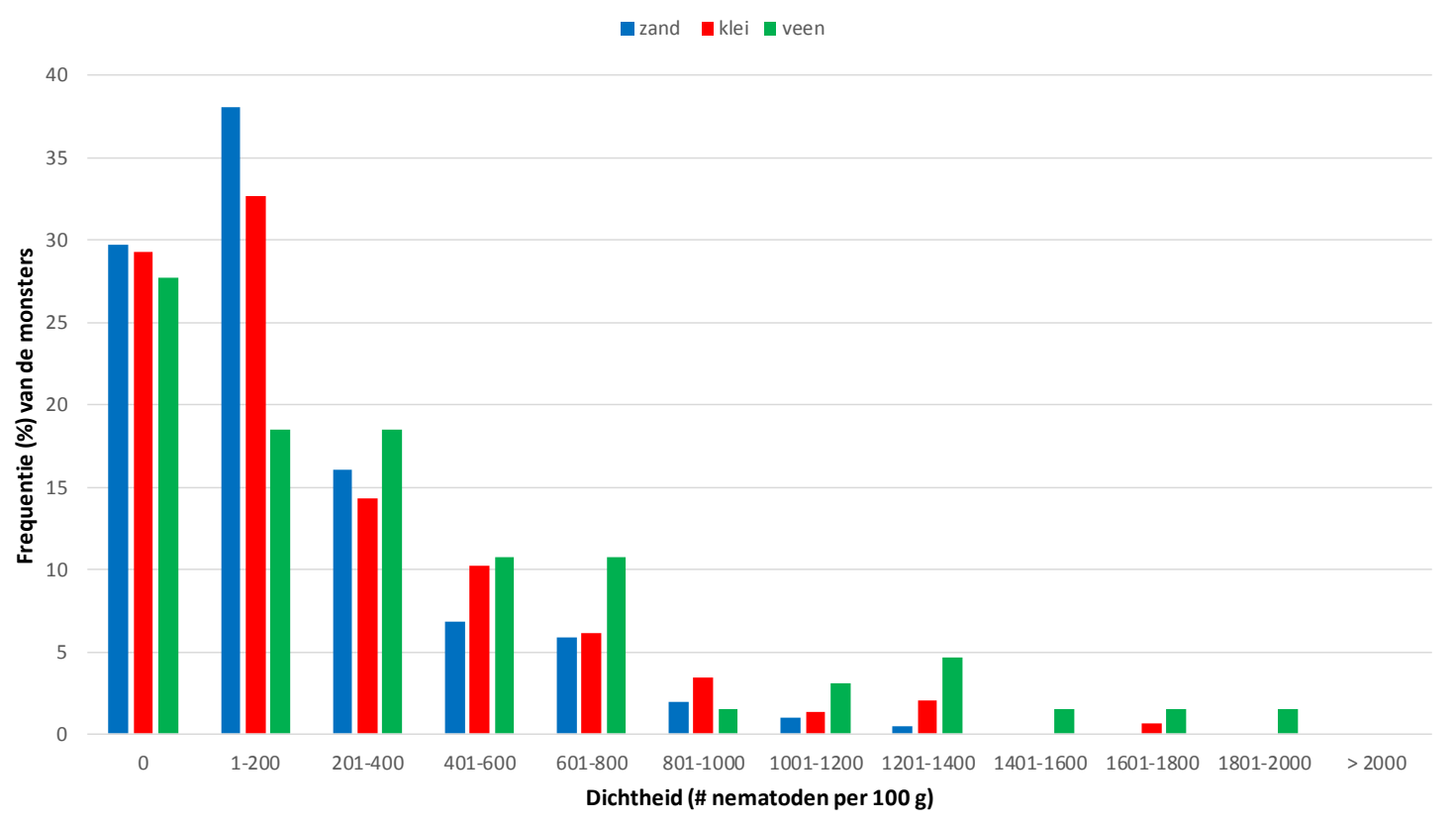

Figuur 5 Frequentieverdeling van de dichtheid van het geslacht Tylenchorhynchus in alle geanalyseerde monsters $(n=417)$, per grondsoort.

\subsubsection{Familie Pratylenchidae}

\section{Aanwezigheid}

De familie Pratylenchidae werd in 381 van de 417 geanalyseerde monsters (91\%) aangetroffen (Tabel 12). Een (verwaarloosbaar) klein deel van alle monsters ( $2 \%$ ) bevatte Pratylenchidae die niet op geslacht gedetermineerd konden worden ('Pratylenchidae sp.'). Van de twee gevonden geslachten kwam Pratylenchus in vrijwel alle monsters voor en werd Pratylenchoides vrijwel niet aangetroffen.

Tabel 12 Aanwezigheid (\%) van de familie Pratylenchidae en bijbehorende geslachten in alle geanalyseerde monsters $(n=417)$, per grondsoort en voor alle grondsoorten samen.

\begin{tabular}{lllll} 
Taxon & Grondsoort & & Veen & Alle \\
& Zand & & & \\
\hline Pratylenchidae & 87 & 94 & 98 & \\
\hline Pratylenchidae sp. ${ }^{1)}$ & & & & \\
\hline Pratylenchus & 1 & 2 & 5 & 2 \\
\hline Pratylenchoides & 86 & 93 & 98 & 91 \\
\hline
\end{tabular}

1) niet op geslacht te determineren

Een verdere uitwerking voor het meest algemene geslacht Pratylenchus op soortniveau laat zien dat in $87 \%$ van alle monsters er soorten aanwezig waren die niet gedetermineerd konden worden (Tabel 13). Van de zeven gedetermineerde soorten kwamen $P$. penetrans en $P$. crenatus in $19 \%$ van de monsters voor; de overige vijf soorten werden gemiddeld sporadisch aangetroffen. 
Tabel 13 Aanwezigheid (\%) van (gedetermineerde) Pratylenchus soorten in alle geanalyseerde monsters $(n=417)$, per grondsoort en voor alle grondsoorten samen.

\begin{tabular}{|c|c|c|c|c|}
\hline \multirow[t]{2}{*}{ Soort } & \multicolumn{4}{|c|}{ Grondsoort } \\
\hline & Zand & Klei & Veen & Alle \\
\hline Pratylenchus sp. ${ }^{1)}$ & 80 & 92 & 97 & 87 \\
\hline Pratylenchus penetrans & 14 & 28 & 18 & 19 \\
\hline Pratylenchus crenatus & 22 & 12 & 23 & 19 \\
\hline Pratylenchus neglectus & 1 & 7 & 2 & 3 \\
\hline Pratylenchus thornei & 0 & 9 & 0 & 3 \\
\hline Pratylenchus vulnus & 0 & 0 & 0 & 0 \\
\hline
\end{tabular}

1) niet op soort te determineren

\section{Dichtheden}

In de monsters waarin Pratylenchidae voorkwam waren van deze familie gemiddeld 226 nematoden $100 \mathrm{~g}^{-1}$ grond aanwezig (Tabel 14). Op zandgrond waren minder Pratylenchidae aanwezig dan op kleiof veengrond. Van het gemiddelde totale aantal nematoden kon $97 \%$ op geslacht gedetermineerd worden. Daarvan was 100\% van het geslacht Pratylenchus. NB: de gerapporteerde dichtheden zijn een onderschatting, omdat de monsters niet waren geïncubeerd. Hierdoor zijn de in de wortels aanwezige nematoden niet meegenomen.

Tabel 14 Gemiddelde dichtheden (\# $100 \mathrm{~g}^{-1}$ grond) van de familie Pratylenchidae en bijbehorende geslachten in de monsters waarin P. voorkwam ( $n=381)$, per grondsoort en voor alle grondsoorten samen.

\begin{tabular}{lllll} 
Taxon & Grondsoort & & Keen & Alle \\
& Zand & & & \\
\hline Pratylenchidae & 138 & 279 & 354 & 226 \\
\hline Pratylenchidae sp. ${ }^{1)}$ & & & & \\
\hline Pratylenchus & 1 & 2 & 30 & 6 \\
\hline Pratylenchoides & 137 & 277 & 324 & 219 \\
\hline
\end{tabular}

1) niet op geslacht te determineren

Van het gemiddelde totale aantal nematoden van het geslacht Pratylenchus kon $11 \%$ op soort gedetermineerd worden (Tabel 15). Hiervan was 45\% van de soort $P$. penetrans, 38\% van de soort $P$. crenatus en de overige $12 \%$ bestond uit de soorten $P$. thornei, P. fallax en $P$. neglectus.

Tabel 15 Gemiddelde dichtheden (\# $100 \mathrm{~g}^{-1}$ grond) van het geslacht Pratylenchus en bijbehorende soorten in de monsters waarin Pratylenchus voorkwam $(n=378)$, per grondsoort en voor alle grondsoorten samen.

\begin{tabular}{|c|c|c|c|c|}
\hline \multirow[t]{2}{*}{ Taxon } & \multicolumn{4}{|c|}{ Grondsoort } \\
\hline & Zand & Klei & Veen & Alle \\
\hline P. sp. ${ }^{1)}$ & 122 & 248 & 297 & 197 \\
\hline P. penetrans & 6 & 16 & 12 & 11 \\
\hline P. thornei & 0 & 5 & 0 & 2 \\
\hline P. fallax & 0 & 1 & 1 & 1 \\
\hline P. neglectus & 0 & 2 & 1 & 1 \\
\hline P. pratensis & 0 & 1 & 0 & 0 \\
\hline P. vulnus & 0 & 0 & 0 & 0 \\
\hline
\end{tabular}


Frequentieverdeling dichtheid van Pratylenchus

De frequentieverdeling van de dichtheid van het geslacht Pratylenchus is gegeven in Figuur 6 . Het geslacht was, afhankelijk van grondsoort, in $2 \%$ (veen) tot $14 \%$ (zand) van alle monsters afwezig.

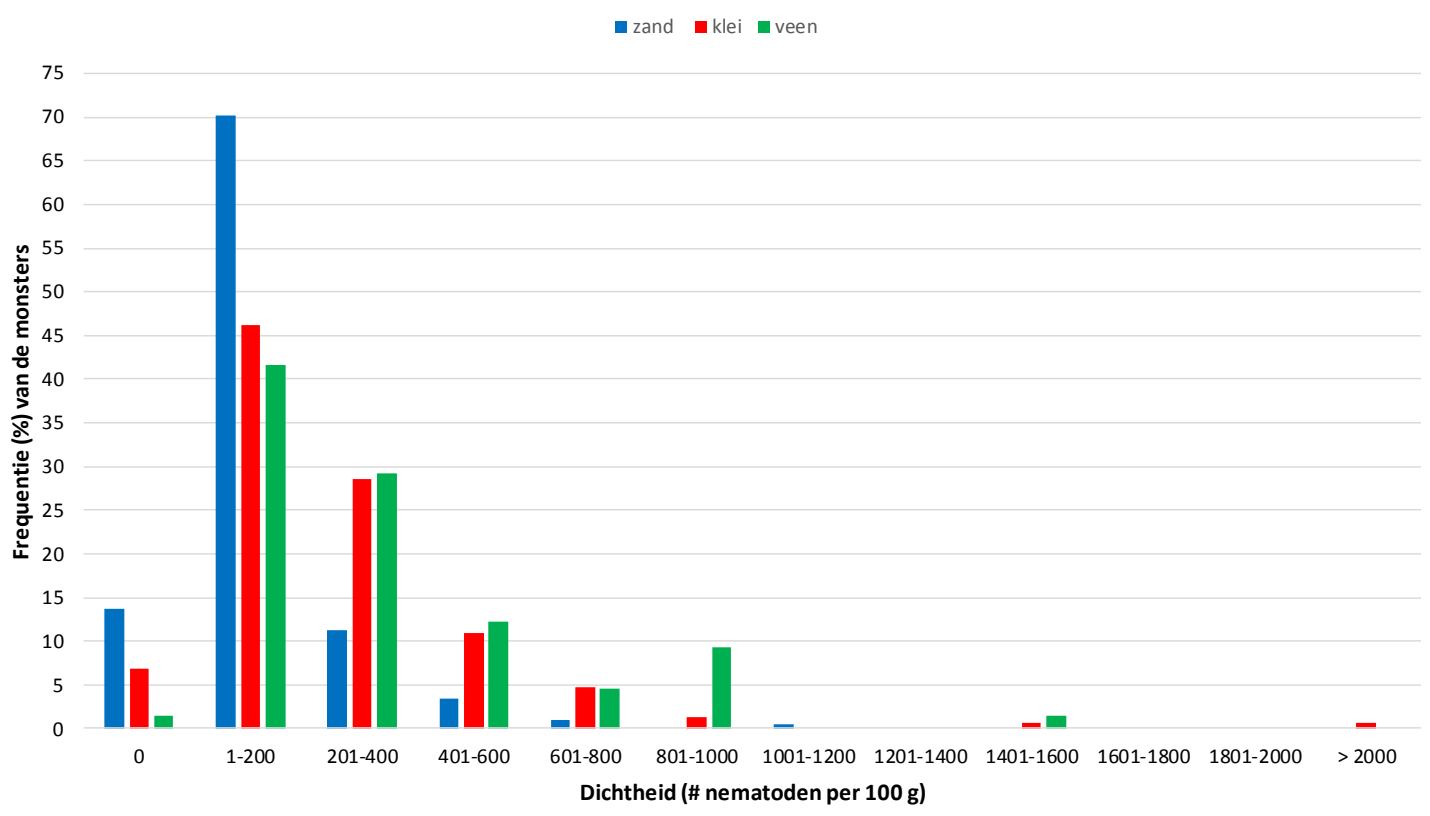

Figuur 6 Frequentieverdeling van de dichtheid van het geslacht Pratylenchus in alle geanalyseerde monsters $(n=417)$, per grondsoort.

\subsubsection{Familie Hoplolaimidae}

\section{Aanwezigheid}

De familie Hoplolaimidae werd in 364 van de 417 geanalyseerde monsters (87\%) aangetroffen (Tabel 16). In $15 \%$ van de monsters waren Hoplolaimidae aanwezig die niet op geslacht gedetermineerd konden worden ('Hoplolaimidae sp.'). Van de twee gevonden geslachten kwam Helicotylenchus in $86 \%$ van de monsters voor en werd het geslacht Rotylenchus in slechts $10 \%$ van de monsters aangetroffen. Het geslacht Helicotylenchus kwam op de drie grondsoorten in gelijke mate voor, terwijl Rotylenchus op kleigrond vaker voorkwam dan op zand- of veengrond.

Tabel 16 Aanwezigheid (\%) van de familie Hoplolaimidae en bijbehorende geslachten in alle geanalyseerde monsters $(n=417)$, per grondsoort en voor alle grondsoorten samen.

\begin{tabular}{lllll} 
Taxon & Grondsoort & & Veen & Alle \\
& Zand & Klei & & \\
\hline Hoplolaimidae & 80 & 95 & 95 & 87 \\
\hline Hoplolaimidae sp. ${ }^{1)}$ & & & & \\
\hline Helicotylenchus & 6 & 30 & 9 & 15 \\
\hline Rotylenchus & 80 & 92 & 95 & 86 \\
\hline
\end{tabular}

1) niet op geslacht te determineren

Een verdere uitwerking voor het geslacht Helicotylenchus op soortniveau laat zien dat in $83 \%$ van alle monsters er Helicotylenchus soorten aanwezig waren die niet gedetermineerd konden worden (Tabel 17). Van de vijf gedetermineerde soorten kwam $H$. pseudorobustus in $27 \%$ van de monsters voor en $H$. varicaudatus in $22 \%$; de overige drie geslachten werden alleen incidenteel aangetroffen. Helicotylenchus pseudorobustus werd op kleigrond minder vaak aangetroffen dan op zand- of 
veengrond en $H$. varicaudatus werd op zandgrond minder vaak aangetroffen dan op klei- of veengrond.

Tabel 17 Aanwezigheid (\%) van (gedetermineerde) Helicotylenchus soorten in alle geanalyseerde monsters $(n=417)$, per grondsoort en voor alle grondsoorten samen.

\begin{tabular}{|c|c|c|c|c|}
\hline \multirow[t]{2}{*}{ Soort } & \multicolumn{4}{|c|}{ Grondsoort } \\
\hline & Zand & Klei & Veen & Alle \\
\hline Helicotylenchus sp. ${ }^{1)}$ & 76 & 90 & 92 & 83 \\
\hline Helicotylenchus pseudorobustus & 39 & 9 & 29 & 27 \\
\hline Helicotylenchus varicaudatus & 6 & 45 & 20 & 22 \\
\hline Helicotylenchus canadensis & 0 & 1 & 0 & 0 \\
\hline Helicotylenchus digonicus & 0 & 0 & 0 & 0 \\
\hline
\end{tabular}

\section{Dichtheden}

In de monsters waarin Hoplolaimidae voorkwam waren van deze familie gemiddeld 270 nematoden $100 \mathrm{~g}^{-1}$ grond aanwezig (Tabel 18). Van dit aantal kon 93\% op geslacht gedetermineerd worden. Van het gemiddelde totale aantal gedetermineerde nematoden (252 $100 \mathrm{~g}^{-1}$ grond, ex. Hoplolaimidae sp.) (Tabel 18 ) was $97 \%$ van het geslacht Helicotylenchus en $3 \%$ van het geslacht Rotylenchus.

Tabel 18 Gemiddelde dichtheden (\# $100 \mathrm{~g}^{-1}$ grond) van de familie Hoplolaimidae en bijbehorende geslachten in de monsters waarin Hoplolaimidae voorkwam $(n=364)$, per grondsoort en voor alle grondsoorten samen.

\begin{tabular}{lllll} 
Taxon & Grondsoort & & Keen & Alle \\
& Zand & & & \\
& & 324 & & \\
\hline Hoplolaimidae & 197 & & & \\
\hline Hoplolaimidae sp. ${ }^{1)}$ & & 38 & 11 & 18 \\
\hline Helicotylenchus & 3 & 271 & 328 & 245 \\
\hline Rotylenchus & 192 & 15 & 2 & 7 \\
\hline
\end{tabular}

1) niet op geslacht te determineren

Van het gemiddelde totale aantal nematoden van het geslacht Helicotylenchus kon $23 \%$ op soort gedetermineerd worden (Tabel 19). Hiervan was 56\% van de soort $H$. pseudorobustus en de overige $44 \%$ van de soort $H$. varicaudatus.

Tabel 19 Gemiddelde dichtheden (\# $100 \mathrm{~g}^{-1}$ grond) van het geslacht Helicotylenchus en bijbehorende soorten in de monsters waarin Helicotylenchus voorkwam $(n=360)$, per grondsoort en voor alle grondsoorten samen.

\begin{tabular}{|c|c|c|c|c|}
\hline \multirow[t]{2}{*}{ Taxon } & \multicolumn{4}{|c|}{ Grondsoort } \\
\hline & Zand & Klei & Veen & Alle \\
\hline Helicotylenchus & 192 & 279 & 328 & 248 \\
\hline H. sp. ${ }^{1)}$ & 140 & 220 & 259 & 191 \\
\hline H. pseudorobustus & 48 & 6 & 46 & 32 \\
\hline H. digonicus & 0 & 0 & 0 & 0 \\
\hline H. paxili & 0 & 0 & 0 & 0 \\
\hline
\end{tabular}

1) niet op soort te determineren 
Frequentieverdeling dichtheid van Helicotylenchus

De frequentieverdeling van de dichtheid van het geslacht Helicotylenchus is gegeven in Figuur 7 . Het geslacht was, afhankelijk van grondsoort, in 5\% (veen) tot $20 \%$ (zand) van het totale aantal monsters afwezig (of kon niet gedetermineerd kon worden).

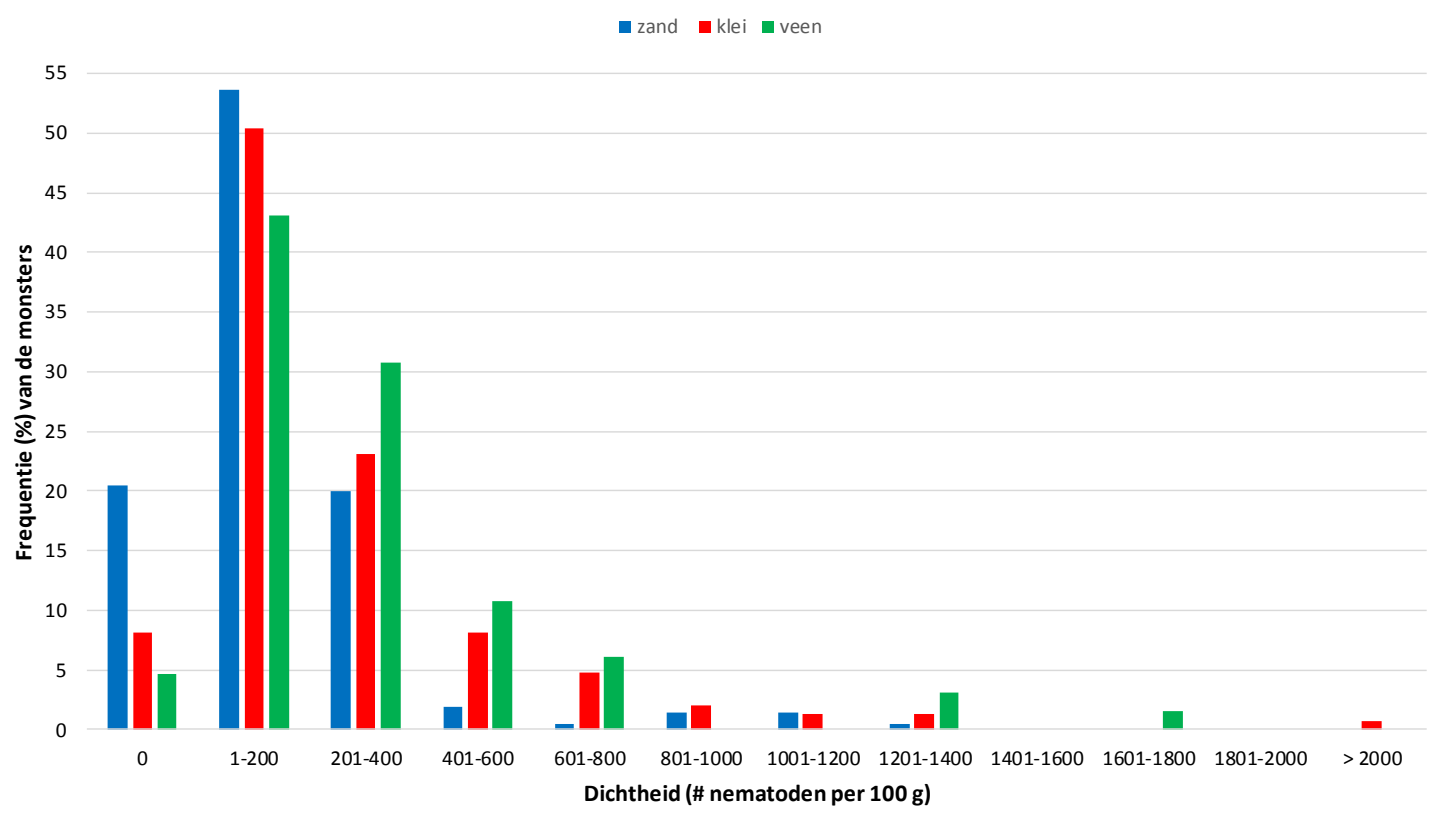

Figuur 7 Frequentieverdeling van de dichtheid van het geslacht Helicotylenchus in alle geanalyseerde monsters $(n=417)$, per grondsoort.

\subsubsection{Familie Tylenchulidae}

\section{Aanwezigheid}

De familie Tylenchulidae werd in 345 van de 417 geanalyseerde monsters (83\%) aangetroffen (Tabel 20). Een (verwaarloosbaar) klein deel $(0,5 \%)$ van de monsters bevatte Tylenchulidae die niet op geslacht gedetermineerd konden worden ('Tylenchulidae sp.'). Van de twee gevonden geslachten kwam Paratylenchus in de meeste monsters voor en werd Gracilacus vrijwel niet aangetroffen. Overigens worden Paratylenchus en Gracilacus tegenwoordig niet meer als aparte geslachten gezien.

Tabel 20 Aanwezigheid (\%) van de familie Tylenchulidae en bijbehorende geslachten in alle geanalyseerde monsters $(n=417)$, per grondsoort en voor alle grondsoorten samen.

\begin{tabular}{lllll} 
Taxon & Grondsoort & & Veen & Alle \\
& Zand & & & \\
\hline Tylenchulidae & 78 & 87 & 89 & \\
\hline Tylenchulidae sp. ${ }^{1)}$ & & & & \\
\hline Paratylenchus & 0 & 1 & 0 & 0 \\
\hline Gracilacus & 78 & 87 & 89 & 83 \\
\hline
\end{tabular}

1) niet op geslacht te determineren

Een verdere uitwerking voor het meest algemene geslacht Paratylenchus op soortniveau laat zien dat in $69 \%$ van alle monsters er soorten aanwezig waren die niet gedetermineerd konden worden (Tabel 21). Van de zeven gedetermineerde soorten kwam $P$. projectus in $32 \%$ van de monsters voor en $P$. nanus in $31 \%$; de overige vijf soorten werden alleen incidenteel aangetroffen. 
Tabel 21 Aanwezigheid (\%) van (gedetermineerde) Paratylenchus soorten in alle geanalyseerde monsters $(n=417)$, per grondsoort en voor alle grondsoorten samen.

\begin{tabular}{|c|c|c|c|c|}
\hline \multirow[t]{2}{*}{ Soort } & \multicolumn{4}{|c|}{ Grondsoort } \\
\hline & Zand & Klei & Veen & Alle \\
\hline Paratylenchus sp. ${ }^{1)}$ & 65 & 73 & 71 & 69 \\
\hline Paratylenchus projectus & 27 & 35 & 40 & 32 \\
\hline Paratylenchus nanus & 26 & 32 & 42 & 31 \\
\hline Paratylenchus microdorus & 0 & 2 & 3 & 1 \\
\hline Paratylenchus hamatus & 1 & 0 & 0 & 1 \\
\hline Paratylenchus bukowinensis & 0 & 1 & 0 & 0 \\
\hline
\end{tabular}

1) niet op soort te determineren

\section{Dichtheden}

In de monsters waarin Tylenchulidae voorkwam waren van deze familie gemiddeld 341 nematoden $100 \mathrm{~g}^{-1}$ grond aanwezig (Tabel 22). Op veengrond waren meer Tylenchulidae aanwezig dan op zandof kleigrond. Van het gemiddelde totale aantal gedetermineerde nematoden (340 $100 \mathrm{~g}^{-1}$ grond) was vrijwel $100 \%$ van het geslacht Paratylenchus.

Tabel 22 Gemiddelde dichtheden (\# $100 \mathrm{~g}^{-1}$ grond) van de familie Tylenchulidae en bijbehorende geslachten in de monsters waarin Tylenchulidae voorkwam $(n=345)$, per grondsoort en voor alle grondsoorten samen.

\begin{tabular}{lllll} 
Taxon & Grondsoort & & Veen & Alle \\
& Zand & & & \\
& & & & \\
& & & \\
Tylenchulidae & 340 & 250 & & \\
\hline Tylenchulidae sp. ${ }^{1)}$ & 0 & 1 & 0 & 0 \\
\hline Paratylenchus & 340 & 248 & 546 & 340 \\
\hline Gracilacus & 0 & 1 & 0 & 0 \\
\hline
\end{tabular}

1) niet op geslacht te determineren

Van het gemiddelde totale aantal nematoden van het geslacht Paratylenchus kon $28 \%$ op soort gedetermineerd worden (Tabel 23). Hiervan was $59 \%$ van de soort $P$. projectus en $38 \%$ van de soort $P$. nanus. De dichtheid van beide soorten was op veengrond hoger dan op zand- of kleigrond.

Tabel 23 Gemiddelde dichtheden (\# $100 \mathrm{~g}^{-1}$ grond) van het geslacht Paratylenchus en bijbehorende soorten in de monsters waarin Paratylenchus voorkwam $(n=345)$, per grondsoort en voor alle grondsoorten samen.

\begin{tabular}{|c|c|c|c|c|}
\hline \multirow[t]{2}{*}{ Taxon } & \multicolumn{4}{|c|}{ Grondsoort } \\
\hline & Zand & Klei & Veen & Alle \\
\hline P. sp. ${ }^{1)}$ & 282 & 165 & 312 & 244 \\
\hline P. projectus & 29 & 45 & 158 & 57 \\
\hline P. microdorus & 0 & 1 & 6 & 1 \\
\hline P. similis & 0 & 1 & 0 & 1 \\
\hline P. bukowinensis & 0 & 0 & 0 & 0 \\
\hline P. hamatus & 1 & 0 & 0 & 0 \\
\hline P. neoamblycephalus & 0 & 0 & 0 & 0 \\
\hline
\end{tabular}

\footnotetext{
1) niet op soort te determineren
} 
Frequentieverdeling dichtheid van Paratylenchus

De frequentieverdeling van de dichtheid van het geslacht Paratylenchus is gegeven in Figuur 8 . Het geslacht was in $11 \%$ (veen) tot $22 \%$ (zand) van alle monsters afwezig.

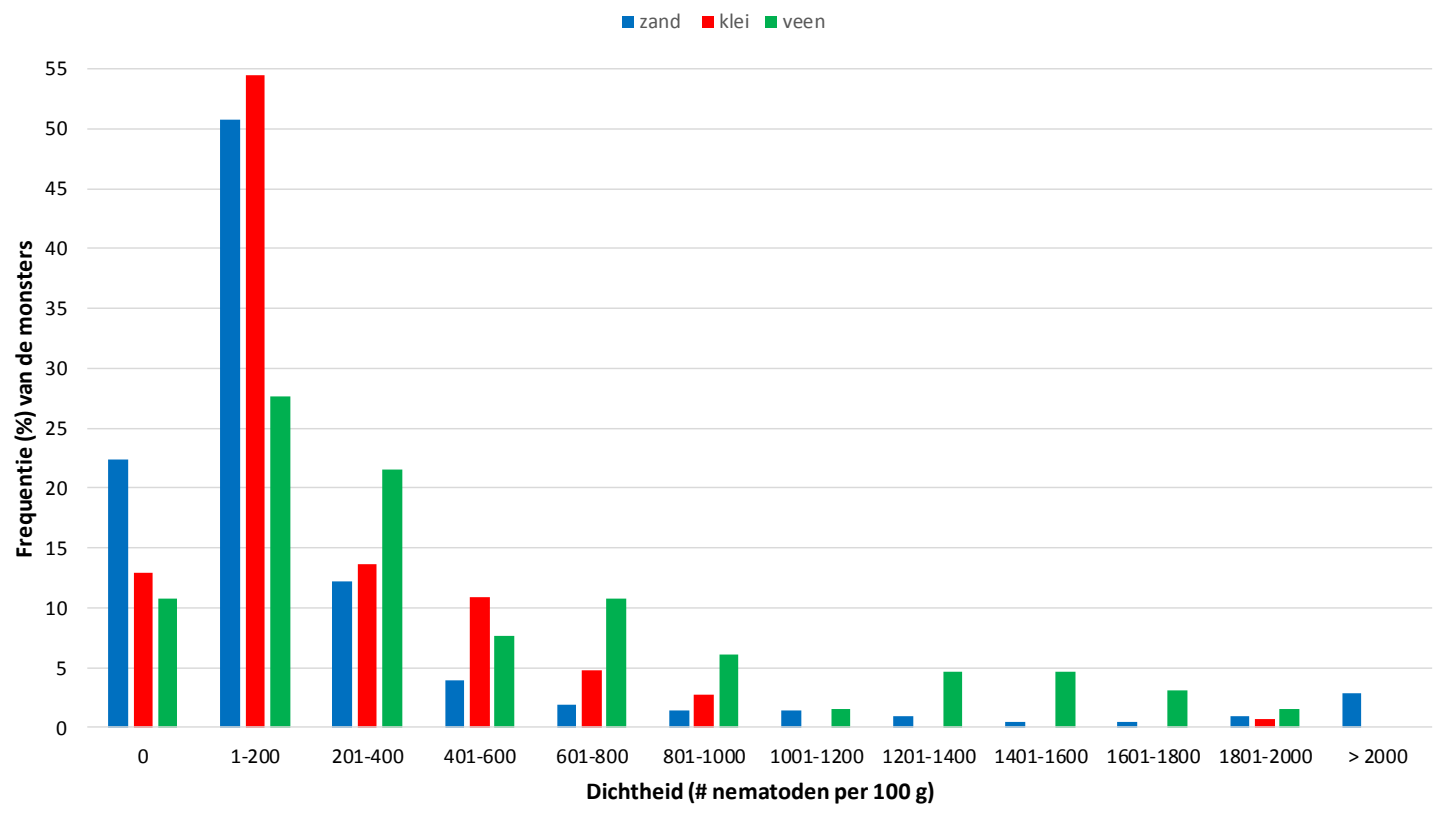

Figuur 8 Frequentieverdeling van de dichtheid van het geslacht Paratylenchus in alle geanalyseerde monsters $(n=417)$, per grondsoort.

\subsubsection{Familie Meloidogynidae}

\section{Aanwezigheid}

De familie Meloidogynidae werd in 337 van de 417 geanalyseerde monsters ( $81 \%$ ) aangetroffen (Tabel 24). De familie bestaat uit één geslacht (Meloidogyne) waardoor alle waarnemingen ook minimaal op geslachtsniveau gedetermineerd werden.

Tabel 24 Aanwezigheid (\%) van de familie Meloidogynidae en haar enige geslacht in alle geanalyseerde monsters $(n=417)$, per grondsoort en voor alle grondsoorten samen.

\begin{tabular}{llcll} 
Taxon & Grondsoort & & Veen & Alle \\
& Zand & Klei & & \\
\hline Meloidogynidae & & & 94 & 81 \\
\hline Meloidogyne & 72 & 87 & & 94 \\
\hline
\end{tabular}

Een verdere analyse voor het geslacht Meloidogyne op soortniveau laat zien dat in $19 \%$ van de monsters er Meloidogyne soorten aanwezig waren die niet gedetermineerd konden worden (Tabel 25). Van de vier gedetermineerde soorten kwam $M$. naasi in $65 \%$ van de monsters voor; de overige drie soorten werden incidenteel aangetroffen. 
Tabel 25 Aanwezigheid (\%) van (gedetermineerde) Meloidogyne soorten in alle geanalyseerde monsters $(n=417)$, per grondsoort en voor alle grondsoorten samen.

\begin{tabular}{lllll} 
& Grondsoort & & Veen & Alle \\
\hline Meloidogyne sp. ${ }^{1)}$ & Zand & Klei & 29 & 34 \\
\hline Meloidogyne naasi & 8 & 63 & 65 & 65 \\
\hline Meloidogyne chitwoodi & 68 & 1 & 0 & 1 \\
\hline Meloidogyne hapla & 0 & 0 & 0 & 0 \\
\hline Meloidogyne fallax & 1 & 0 & 0 & 0 \\
\hline
\end{tabular}

1) niet op soort te determineren

\section{Dichtheden}

In de monsters waarin Meloidogynidae voorkwam waren van deze familie gemiddeld 270 nematoden $100 \mathrm{~g}^{-1}$ grond aanwezig, afkomstig van het enige geslacht Meloidogyne (Tabel 26). De gemiddelde dichtheid van dit geslacht was op veengrond hoger dan op zand- of kleigrond. NB: de gerapporteerde dichtheden zijn een onderschatting, omdat de monsters niet waren geïncubeerd. Hierdoor zijn de in de wortels aanwezige nematoden niet meegenomen.

Tabel 26 Gemiddelde dichtheden (\# $100 \mathrm{~g}^{-1}$ grond) van de familie Meloidogynidae en haar enige geslacht Meloidogyne in de monsters waarin Meloidogynidae voorkwam $(n=337)$, per grondsoort en voor alle grondsoorten samen.

\begin{tabular}{lcccc} 
Taxon & Grondsoort & & Veen & Alle \\
& Zand & Klei & & \\
\hline Meloidogynidae & 193 & 256 & 487 & 270 \\
\hline Meloidogyne & & & & \\
\hline
\end{tabular}

Van het gemiddelde totale aantal nematoden van het geslacht Meloidogyne kon $77 \%$ op soort gedetermineerd worden (Tabel 27 ); hiervan was vrijwel $100 \%$ van de soort M. naasi.

Tabel 27 Gemiddelde dichtheden (\# $100 \mathrm{~g}^{-1}$ grond) van het geslacht Meloidogyne en bijbehorende soorten in de monsters waarin M. voorkwam $(n=337)$, per grondsoort en voor alle grondsoorten samen.

\begin{tabular}{|c|c|c|c|c|}
\hline \multirow[t]{2}{*}{ Taxon } & \multicolumn{4}{|c|}{ Grondsoort } \\
\hline & Zand & Klei & Veen & Alle \\
\hline M. sp. ${ }^{1)}$ & 9 & 57 & 204 & 63 \\
\hline M. naasi & 183 & 198 & 284 & 207 \\
\hline M. hapla & 1 & 0 & 0 & 0 \\
\hline
\end{tabular}

1) niet op soort te determineren 


\section{Frequentieverdeling dichtheid van Meloidogyne}

De frequentieverdeling van de dichtheid van het geslacht Meloidogyne is gegeven in Figuur 9. Het geslacht was in $6 \%$ (veen) tot $28 \%$ (zand) van alle monsters afwezig.

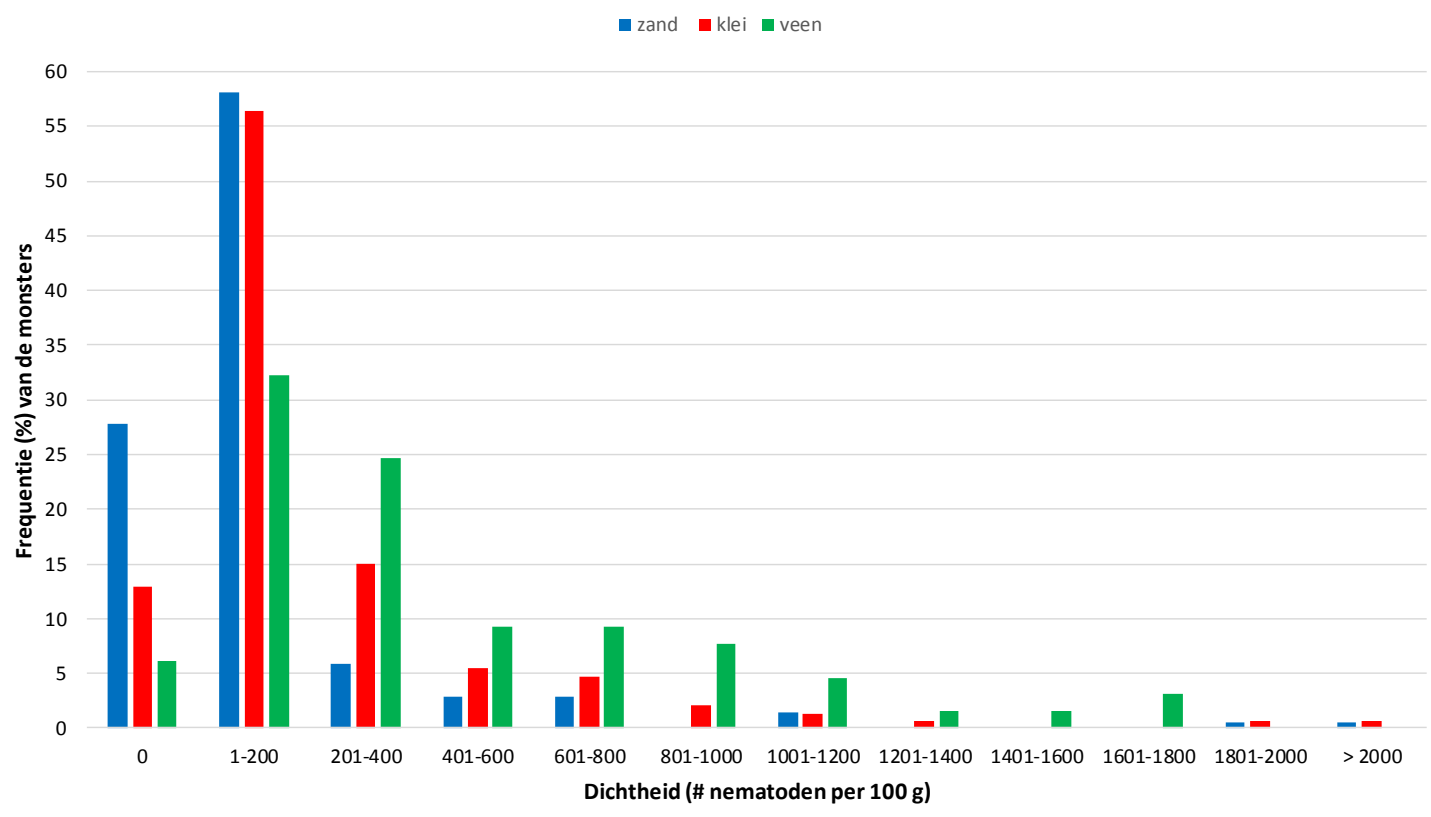

Figuur 9 Frequentieverdeling van de dichtheid van het geslacht Meloidogyne in alle geanalyseerde monsters $(n=417)$, per grondsoort.

\subsection{Gecorrigeerde dichtheden}

Correctie van de dichtheden van de vijf meest aangetroffen parasitaire geslachten voor het aandeel niet-gedetermineerde nematoden had het grootste effect bij het geslacht Tylenchorhynchus. Bij dit geslacht nam de gemiddelde dichtheid (voor alle grondsoorten samen) toe van 348 tot 720 nematoden $100 \mathrm{~g}^{-1}$ (Tabel 28). Bij de geslachten Pratylenchus en Helicotylenchus waren de toenames klein en bij de geslachten Paratylenchus en Meloidogyne veranderden de dichtheden niet.

Tabel 28 Gemiddelde dichtheden (\# $100 \mathrm{~g}^{-1}$ grond) van de vijf meest aangetroffen parasitaire geslachten, gecorrigeerd voor de niet op geslacht gedetermineerde aantallen van de bijbehorende familie, per grondsoort en voor alle grondsoorten samen.

\begin{tabular}{|c|c|c|c|c|}
\hline \multirow[t]{2}{*}{ Geslacht } & \multicolumn{4}{|c|}{ Grondsoort } \\
\hline & Zand & Klei & Veen & Alle \\
\hline Tylenchorhynchus - origineel & 277 & 356 & 547 & 348 \\
\hline Tylenchorhynchus - gecorrigeerd & 877 & 526 & 774 & 720 \\
\hline Pratylenchus - origineel & 139 & 279 & 324 & 221 \\
\hline Helicotylenchus - origineel & 192 & 279 & 328 & 248 \\
\hline Helicotylenchus - gecorrigeerd & 195 & 317 & 338 & 265 \\
\hline Paratylenchus - origineel & 340 & 248 & 546 & 340 \\
\hline Paratylenchus - gecorrigeerd & 340 & 249 & 546 & 341 \\
\hline Meloidogyne - gecorrigeerd & 193 & 256 & 487 & 270 \\
\hline
\end{tabular}




\section{$4 \quad$ Discussie}

\subsection{Methodiek}

\subsubsection{Representativiteit van de bemonstering}

In de bedrijfsbrede bemonstering werden ook percelen bouwland, met andere gewassen dan (blijvend) grasland, meegenomen. Meestal is dat gewas snijmaïs, het tweede belangrijkste voedergewas in de Nederlandse melkveehouderij. Door het meenemen van bouwland kan het aantal aangetroffen taxa hoger zijn als bepaalde taxa wel in bouwland maar niet in blijvend grasland aanwezig zijn. Daarnaast kan er ook een verdunning zijn geweest van de dichtheden van taxa die vooral in blijvend grasland aanwezig zijn of daar in hogere dichtheden aanwezig zijn. Om een verdunnend effect van het areaal bouwland te kunnen schatten, is het nodig om te weten welk percentage van het totale bemonsterde areaal uit bouwland bestond. Dit is maar voor een deel van de bedrijven in de database vastgelegd. Rutgers et al. (2007) noemen een gemiddeld percentage bouwland op Nederlandse melkveebedrijven van $23 \%$ (gegevens uit de BoBI-database d.d. 15 oktober 2005). Dit percentage kan bij (intensieve) bedrijven op zandgrond hoger zijn dan bij bedrijven op kleigrond. Bij bedrijven op veengrond is meestal weinig tot geen bouwland aanwezig. Om de invloed van vooral snijmaïs op de soorten en aantallen nematoden te achterhalen, kan mogelijk gebruik gemaakt worden van de dichtheid van nematodensoorten die zich onder snijmaïs veel beter vermeerderen dan in grasland. In de database zijn echter geen soorten aanwezig die in dat opzicht duidelijk verschillen.

Een mogelijk verdunnend effect zal de grootste invloed gehad hebben in de periode van $1993 \mathrm{t} / \mathrm{m}$ 2006 , toen er nog geen sprake was van derogatie (met verplichting tot minimaal $80 \%$ grasland in het bedrijfsareaal) en waardoor het aandeel snijmaïs in het areaal gemiddeld hoger zal zijn geweest. In deze periode is 66\% van alle monsters genomen (Figuur 2). Na 2006 is de mogelijke invloed van snijmaïs beperkter, vanwege de invoering van derogatie die door het merendeel van de melkveebedrijven ook is aangevraagd.

\subsubsection{Bemonsterings- en extractiemethode}

De dichtheden van sommige families zijn mogelijk, en in een aantal gevallen zeker, onderschat, omdat de gebruikte bemonsterings- en extractiemethoden niet waren toegespitst op deze families. Het betreft hier vooral de families Pratylenchidae (aanwezig in 91\% van de monsters), Meloidogynidae (81\%), Heteroderidae (37\%), Trichodoridae (24\%), Longidoridae (10\%) en Criconematidae (5\%).

Bij de Meloidogynidae en Pratylenchidae geeft incubatie van wortelmateriaal hogere dichtheden, omdat dan ook de in de wortels aanwezige nematoden worden meegenomen. Incubatie wordt echter niet standaard uitgevoerd, waardoor de gevonden dichtheden na incubatie moeilijk te vergelijken zijn met dichtheden zonder incubatie. Bij de Heteroderidae geeft het ontbreken van cystenonderzoek een onderschatting van de werkelijke dichtheden. Het ontbreken van cystenonderzoek kan ook de reden zijn dat het geslacht Punctodera niet werd aangetroffen (Fleming et al. 2016). Om de dichtheid van de familie Trichodoridae betrouwbaar vast te stellen, moet er tenminste tot $30 \mathrm{~cm}$ diep bemonsterd worden (in plaats van tot $10 \mathrm{~cm}$ ), aangezien deze nematoden zich over de diepte van de bouwvoor kunnen verplaatsen. In de akkerbouw wordt tot $23 \mathrm{~cm}$ diepte bemonsterd. Ook bij de familie Longidoridae zou dieper bemonsterd moeten worden. Bij de familie Criconematidae zou een andere extractiemethode toegepast moeten worden; de nematoden van deze familie zijn sterk geringd en kunnen het gebruikte wattenfilter moeilijk passeren.

De families waarvoor de bemonsterings- en verwerkingsmethodiek voldoende passend was, waardoor de gerapporteerde dichtheden voor de laag $0-10 \mathrm{~cm}$ voldoende nauwkeurig zijn vastgesteld, zijn de Tylenchidae, Dolichodoridae, Hoplolaimidae, en Tylenchulidae. Deze families vertegenwoordigen het overgrote deel $(80 \%)$ van de gerapporteerde totale gemiddelde dichtheid van de herbivore nematoden 
in de laag 0-10 cm (Tabel 5). Verschoor et al. (2001) en anderen laten zien dat de meeste soorten nematoden ook dieper in de grond in behoorlijke aantallen aanwezig kunnen zijn. Om de volledige dichtheid van soorten vast te stellen, zou standaard beter tot $30 \mathrm{~cm}$ diepte bemonsterd kunnen worden, gevolgd door incubatie van de monsters voor minimaal twee weken.

\subsubsection{Determinatie}

Bij een aantal families en/of geslachten kon maar een beperkt deel van de nematoden op geslacht en/of soort gedetermineerd worden. De belangrijkste reden hiervoor was dat het juveniele exemplaren betrof, waarbij de geslachts- of soortkenmerken onvoldoende duidelijk vastgesteld konden worden. In een zeer beperkt deel van de gevallen kan er ook sprake geweest zijn van soorten die in Nederland niet eerder zijn aangetroffen of niet eerder zijn beschreven (en daardoor 'onbekend'). Een voorbeeld daarvan is de soort Meloidogyne minor, die in 2000 voor het eerst in Nederland werd aangetroffen en in 2004 voor het eerst werd beschreven (Karssen et al. 2004). Omdat een groot deel van de monsters (52\%) in de gebruikte dataset voor 2004 zijn genomen, en ook na 2004 de determinatie nog lastig geweest kan zijn, bestaat een deel van de niet-gedetermineerde Meloidogyne mogelijk uit M. minor.

Van de vijf meer in detail geanalyseerde families kon bij de Dolichodoridae $52 \%$ van de nematoden niet op geslacht worden gedetermineerd en van het meest aangetroffen geslacht (Tylenchorhynchus) kon $64 \%$ van de nematoden niet op soort worden gedetermineerd. Bij de Pratylenchidae en Pratylenchus was dit respectievelijk 3\% en $89 \%$, bij de Hoplolaimidae en Helicotylenchus $7 \%$ en $77 \%$, bij de Tylenchulidae en Paratylenchus $0 \%$ en $72 \%$, en bij de Meloidogynidae en Meloidogyne $0 \%$ en 23\%. Wanneer maar een beperkt deel van de nematoden op geslacht en/of soort gedetermineerd kan worden, zijn de dichtheden per geslacht en/of soort vrijwel zeker onderschat. Geconstateerd kan worden dat de gerapporteerde dichtheden van de geslachten Pratylenchus, Helicotylenchus, Paratylenchus en Meloidogyne, op grond van determinatiepercentages, een redelijk tot goede weergave zijn van de werkelijke dichtheden in de geanalyseerde monsters (afgezien van de bijdrage uit de wortels bij Pratylenchus en Meloidogyne), terwijl de dichtheid van Tylenchorhynchus zeker onderschat is. De toegepaste correctie voor het aandeel niet-gedetermineerde nematoden leidde tot een aanzienlijke aanpassing van de gemiddelde dichtheid van Tylenchorhynchus (Tabel 28), met bijna een verdubbeling van het aantal.

Een dergelijke correctie kan ook gemaakt worden voor de meest aangetroffen soort binnen het geslacht Tylenchorhynchus, T. dubius, maar is in deze studie niet uitgevoerd. De gecorrigeerde dichtheden kunnen ook effect hebben op de gerapporteerde frequentieverdelingen, maar deze verdelingen zijn op basis van de correctie (nog) niet aangepast. Het grote effect van het aantal nietgedetermineerde exemplaren op de gerapporteerde dichtheden van sommige geslachten en soorten onderstreept het belang van een zo volledig mogelijk uitgevoerd determinatie.

\subsection{Populatieveranderingen in de tijd}

Wanneer het overzicht uit de huidige inventarisatie wordt vergeleken met oude gegevens (19501980), dan wekt dit de indruk dat er tussentijds mogelijk belangrijke verschuivingen zijn opgetreden in de aanwezigheid en dichtheid van sommige soorten. Dit kan met een aantal voorbeelden worden geïllustreerd. Simons (1973) vermeldt (kwantitatief) dat Rotylenchus uniformis (voor 1996 benoemd als $R$. robustus), naast Tylenchorhynchus dubius, in Nederland de meest voorkomende ectoparasiet op zandgrond is. Echter, in de huidige inventarisatie wordt deze soort vrijwel niet aangetroffen; het geslacht Rotylenchus kwam in 3\% van de monsters op zandgrond voor, met een gemiddelde dichtheid in deze monsters van 41 specimen $100 \mathrm{~g}^{-1}$ grond. Omdat $98 \%$ van de Hoplolaimidae op zandgrond op geslacht gedetermineerd kon worden, en er geen specifieke bemonsteringsmethodiek voor deze soort nodig is, is deze waarneming betrouwbaar. Op kleigrond werd Rotylenchus overigens vaker aangetroffen, in $20 \%$ van de monsters en met een gemiddelde dichtheid van 68 specimen $100 \mathrm{~g}^{-1}$ grond.

Pratylenchus pratensis kwam volgens Oostenbrink (1954) in het verleden regelmatig voor in oud grasland op zandgrond, en volgens Bongers (1988) komt $P$. pratensis in Nederland algemeen voor op 
zwaardere grond, o.a. in prei. In een inventarisatie door Oostenbrink (1954) op een gemengd bedrijf varieerde de dichtheid van het geslacht Pratylenchus in grasland tussen de 0 en 235 specimen $100 \mathrm{~g}^{-1}$ grond en was $P$. pratensis binnen het geslacht de dominante soort. In de huidige inventarisatie komt deze soort vrijwel niet voor; $P$. pratensis werd aangetroffen op slechts één bedrijf, met een dichtheid van 182 specimen $100 \mathrm{~g}^{-1}$ grond.

Helicotylenchus is een geslacht dat mogelijk talrijker is dan voorheen. In oude (Nederlandse) literatuur (Oostenbrink et al., 1950-1970) wordt Helicotylenchus weinig genoemd, hoewel het geslacht al in 1945 beschreven was. In de huidige inventarisatie was dit geslacht in $86 \%$ van alle monsters aanwezig (Tabel 16), met in deze monsters een gemiddelde dichtheid van 248 specimen $100 \mathrm{~g}^{-1} \mathrm{grond}$ (Tabel 19). Omdat van de bijbehorende familie Hoplolaimidae $93 \%$ van de nematoden op geslacht gedetermineerd kon worden, is dit een betrouwbare waarneming. Bovenstaande gegevens duiden op een mogelijke verschuiving in de soortsamenstelling over de afgelopen decennia. Fleming et al. (2016) suggereerden een dergelijke verschuiving voor Noord-Ierland, waarbij deze verschuiving (ook) gelinkt werd aan veranderingen in gewasmanagement.

Waarschijnlijk heeft er in de laatste decennia ook een verschuiving in de totale dichtheden van herbivore nematoden in Nederlands productiegrasland plaatsgevonden. Oostenbrink (1966) rapporteerde een gemiddeld aantal herbivore nematoden van $5620100^{-1} \mathrm{ml}$ grond in 72 Nederlandse weiden. Dit is meer dan het dubbele van het gemiddelde gevonden aantal in de huidige inventarisatie (Tabel 5). Hierbij wordt aangetekend dat de dataset van Oostenbrink (1966) in verhouding klein was en er geen onderscheid naar grondsoort gemaakt werd.

\subsection{Schade}

De hoofddoelstelling van deze studie was om een zo recent mogelijk overzicht te krijgen van soorten en dichtheden van PPN in productiegrasland. Een belangrijke achterliggende vraag is of op basis van de aangetroffen soorten en dichtheden iets gezegd kan worden over de opbrengstderving. De Boer (2018) schatte de opbrengstderving van Nederlands productiegrasland als gevolg van aantasting door PPN op gemiddeld 1,2 ton DS ha-1 jaar-1, voor de periode 1950 tot 1980 . Het actuele niveau van opbrengstderving is onbekend. Voor het schatten of berekenen van het actuele niveau van opbrengstderving zouden de gevonden dichtheden van de schadelijke soorten vergeleken kunnen worden met hun schadedrempels, de dichtheid waarboven opbrengstderving optreedt. Als voorbeeld kan de schadelijke endoparasiet Pratylenchus pratensis worden gebruikt. Oostenbrink (1954) beschouwde dichtheden $P$. pratensis van 100-200 specimen $100 \mathrm{~g}^{-1}$ grond in grasland als relatief hoog. Wordt de bovengrens van deze range voor het hele geslacht Pratylenchus als schadedrempel gehanteerd, dan zou op minimaal $16 \%, 47 \%$ en $57 \%$ van alle bedrijven op respectievelijk zand-, kleien veengrond er sprake geweest zijn van schade door dit geslacht (Figuur 6).

Het probleem met schadedrempels is dat ze afhankelijk zijn van groeiomstandigheden en opbrengstniveaus, waardoor vertaling naar daadwerkelijke schade onder veldomstandigheden lastig is (De Boer 2018). De weinige schadedrempels die voor grasland gehanteerd kunnen worden zijn meestal vastgesteld onder specifieke en nogal wisselende omstandigheden. Ook werden deze schadedrempels bijna altijd vastgesteld per soort, waardoor geen rekening werd gehouden met het effect van interacties tussen meerdere schadelijke soorten. Het is daarom niet mogelijk om op basis van deze (oude) schadedrempels een betrouwbare indruk van het niveau van (samengestelde) schade in de vorm van opbrengstderving te geven.

Ontsmettingsproeven onder veldomstandigheden lijken momenteel de beste optie om het actuele niveau van opbrengstderving in grasland te schatten (De Boer 2018). Nieuwe schadedrempels, te ontwikkelen met behulp van de actuele inzichten en op basis van een gestandaardiseerd protocol, bieden mogelijk ook perspectief om gemeten dichtheden te vertalen naar het niveau van opbrengstderving. 


\section{Reflectie en aanbevelingen}

De voorliggende inventarisatie is de eerste analyse van de herbivore nematodenfauna in Nederlands productiegrasland op nationaal niveau. Deze unieke resultaten geven goede indicaties van de aanwezigheid en minimale dichtheden van families, geslachten en soorten herbivore nematoden in Nederlands productiegrasland. Het overzicht is echter voor een aantal taxa nog niet volledig, omdat bij de dataverzameling een aantal specifieke bemonsterings- en verwerkingsmethoden niet zijn toegepast. Daarnaast zijn de gebruikte gegevens, hoewel relatief recent, toch gemiddeld 16 jaar oud. Veranderingen in het graslandmanagement hebben sindsdien waarschijnlijk geleid tot veranderingen in soortsamenstelling en dichtheden. Om een actueel overzicht te krijgen is een nieuwe nationale inventarisatie nodig.

Het graslandmanagement blijft veranderen. Nieuwe ontwikkelingen zijn het stimuleren van kruidenrijk grasland, meer beweiden, en een toenemende vervanging van kunstmest door organische mest. De doorgaande veranderingen maken het noodzakelijk om een nationale kartering regelmatig te herhalen, bijvoorbeeld eens per tien jaar. Hierdoor kunnen veranderingen in de herbivore nematodenfauna worden gevolgd en kan desgewenst het graslandmanagement worden aangepast. De resultaten kunnen verder ook gebruikt worden om de bijdrage van herbivore nematoden aan biodiversiteit, en veranderingen daarin, te monitoren.

Een nieuwe kartering heeft een andere aanpak nodig dan destijds gekozen voor BoBI en dient gericht te worden op het specifieke gewas en specifieke doelstellingen. Bij het formuleren van de aanpak kunnen de in het huidige onderzoek opgedane ervaringen worden gebruikt om de kwaliteit van een nieuwe kartering te maximaliseren. 


\section{Conclusies}

- Analyse van gegevens uit de BoBI-database maakt het voor de eerste keer mogelijk om voor Nederland een overzicht te geven van de aanwezigheid en minimale dichtheden van families, geslachten en soorten van herbivore en plantparasitaire nematoden in productiegrasland;

- Het overzicht is voor een aantal taxa nog niet volledig vanwege een aantal beperkingen bij de destijds uitgevoerde monstername en -verwerking;

- In de gebruikte monsters (van 417 melkveebedrijven) waren 106 herbivore taxa aanwezig, die konden worden ondergebracht in 14 families, 38 geslachten, en 61 soorten;

- De zes meest aangetroffen families waren de Tylenchidae (in 100\% van de monsters), Dolichodoridae (97\%), Pratylenchidae (91\%), Hoplolaimidae (87\%), Tylenchulidae (83\%), en Meloidogynidae (81\%). Minder vaak aangetroffen families waren de Heteroderidae (37\%), Trichodoridae (24\%), Longidoridae (15\%), en Criconematidae (8\%);

- De vijf meest aangetroffen parasitaire geslachten waren Pratylenchus (in $91 \%$ van alle monsters), Helicotylenchus (86\%), Paratylenchus (83\%), Meloidogyne (81\%), en Tylenchorhynchus (71\%);

- De gemiddelde dichtheden van deze geslachten waren respectievelijk 348 (Tylenchorhynchus), 221 (Pratylenchus), 248 (Helicotylenchus), 340 (Paratylenchus), en 270 (Meloidogyne) specimen $100 \mathrm{~g}^{-1}$ grond;

- De gemiddelde dichtheid van Pratylenchus en Meloidogyne is onderschat vanwege het ontbreken van incubatieonderzoek; de gemiddelde dichtheid van Tylenchorhynchus is onderschat omdat een aanzienlijk deel van hun familie (Dolichodoridae) niet op geslacht gedetermineerd kon worden;

- Na een correctie voor de niet-gedetermineerde Dolichodoridae nam de gemiddelde dichtheid van Tylenchorhynchus toe van 348 tot 720 specimen $100 \mathrm{~g}^{-1}$ grond;

- De dichtheidsfrequenties van de vijf meest aangetroffen schadelijke geslachten kunnen gebruikt worden om een indruk te krijgen van het aandeel bedrijven waarop schade wordt veroorzaakt. Hiervoor dienen echter eerst betrouwbare schadedrempels te worden ontwikkeld;

- De dichtheid van herbivore nematoden in productiegrasland is mogelijk over de laatste decennia afgenomen. Ook de soortsamenstelling is waarschijnlijk veranderd; soorten die vroeger regelmatig voorkwamen (zoals Rotylenchus uniformis en Pratylenchus penetrans) werden in de huidige inventarisatie vrijwel niet meer aangetroffen;

- Een nieuw nationaal systeem van monitoring is nodig om een actueel beeld te krijgen en te houden van de aanwezigheid van herbivore en plantparasitaire nematoden in productiegrasland, en van hun bijdrage aan biodiversiteit. 


\section{Dankwoord}

Wij danken Leendert Molendijk (Wageningen Plant Research), Gerard Korthals (Wageningen Plant Research/NIOO) en Joeke Postma (Wageningen Plant Research) voor hun kritische review van een conceptversie van dit rapport. Wageningen Livestock Research voerde dit onderzoek uit, samen met LIOS en het RIVM, voor het Ministerie van Landbouw, Natuur en Voedselkwaliteit, binnen het Kennisbasisproject Bodemindicatoren (KB-21-002-010). 


\section{Literatuur}

Bongers T (1988) De nematoden van Nederland. Koninklijke Nederlandse Natuurhistorische Vereniging, Utrecht

De Boer HC (2018) Betekenis van plantparasitaire nematoden voor Nederlands productiegrasland. Rapport 1142, Wageningen Livestock Research, Wageningen

Fleming TR, McGowan NE, Maule AG, Fleming CC (2016) Prevalence and diversity of plant parasitic nematodes in Northern Ireland grassland and cereals, and the influence of soils and rainfall. Plant Pathology 65:1539-1550

Karssen G, Bolk RJ, Van Aelst AC, Van den Beld I, Kox LFF, Korthals G, Molendijk L, Zijlstra C, Van Hoof R, Cook R (2004) Description of Meloidogyne minor n. sp. (Nematoda: Meloidogynidae), a rootknot nematode associated with yellow patch disease in golf courses. Nematology 6:59-72

NEN (2011) Soil quality - Sampling of soil invertebrates - Part 4: Sampling, extraction and identification of soil-inhabiting nematodes. NEN-EN-ISO 23611-4:2011 en.

Oostenbrink M (1954) Over de betekenis van vrijlevende wortelaaltjes in land- en tuinbouw. Verslagen en mededelingen van de Plantenziektekundige Dienst 124:196-233

Oostenbrink M (1957) Nematoden in verband met de vruchtbaarheid van de grond. Veenman \& Zonen, Wageningen

Oostenbrink M (1966) Major characteristics of the relation between nematodes and plants. Mededelingen Landbouwhogeschool Wageningen 66-4, Veenman \& Zonen, Wageningen

Rutgers M, Mulder C, Schouten AJ, Bloem J, Bogte JJ, Breure AM, Brussaard L, De Goede RGM, Faber JH, Jagers op Akkerhuis GAJM, Keidel H, Korthals GW, Smeding FW, Ter Berg C, Van Eekeren N (2007) Typeringen van bodemecosystemen in Nederland met tien referenties voor biologische bodemkwaliteit. RIVM Rapport 607604008/2007, RIVM, Bilthoven

Schouten AJ, Bloem J, Didden W, Jagers op Akkerhuis G, Keidel H, Rutgers M (2002) Bodembiologische indicator 1999 - ecologische kwaliteit van graslanden op zandgrond bij drie categorieën melkveehouderijbedrijven. Rapport 607604003, RIVM, Bilthoven

Simons WR (1973) Nematode survival in relation to soil moisture. Proefschrift Landbouwhogeschool Wageningen, Wageningen

Verschoor BC, De Goede RGM, De Hoop JW, De Vries FW (2001) Seasonal dynamics and vertical distribution of plant-feeding nematode communities in grasslands. Pedobiologia 45:213-233

Yeates GW, Bongers T, De Goede RGM, Freckman DW, Georgieva SS (1993) Feeding habits in soil nematode families and genera - An outline for soil ecologists. Journal of Nematology 25:315-331 


\section{Bijlage 1 Overzicht van aangetroffen herbivore taxa}

Tabel 29 Herbivore nematodentaxa aangetroffen in de geanalyseerde BoBI-dataset, ingedeeld naar voedingswijze, met gemiddelde aantallen per grondsoort of voor alle grondsoorten samen

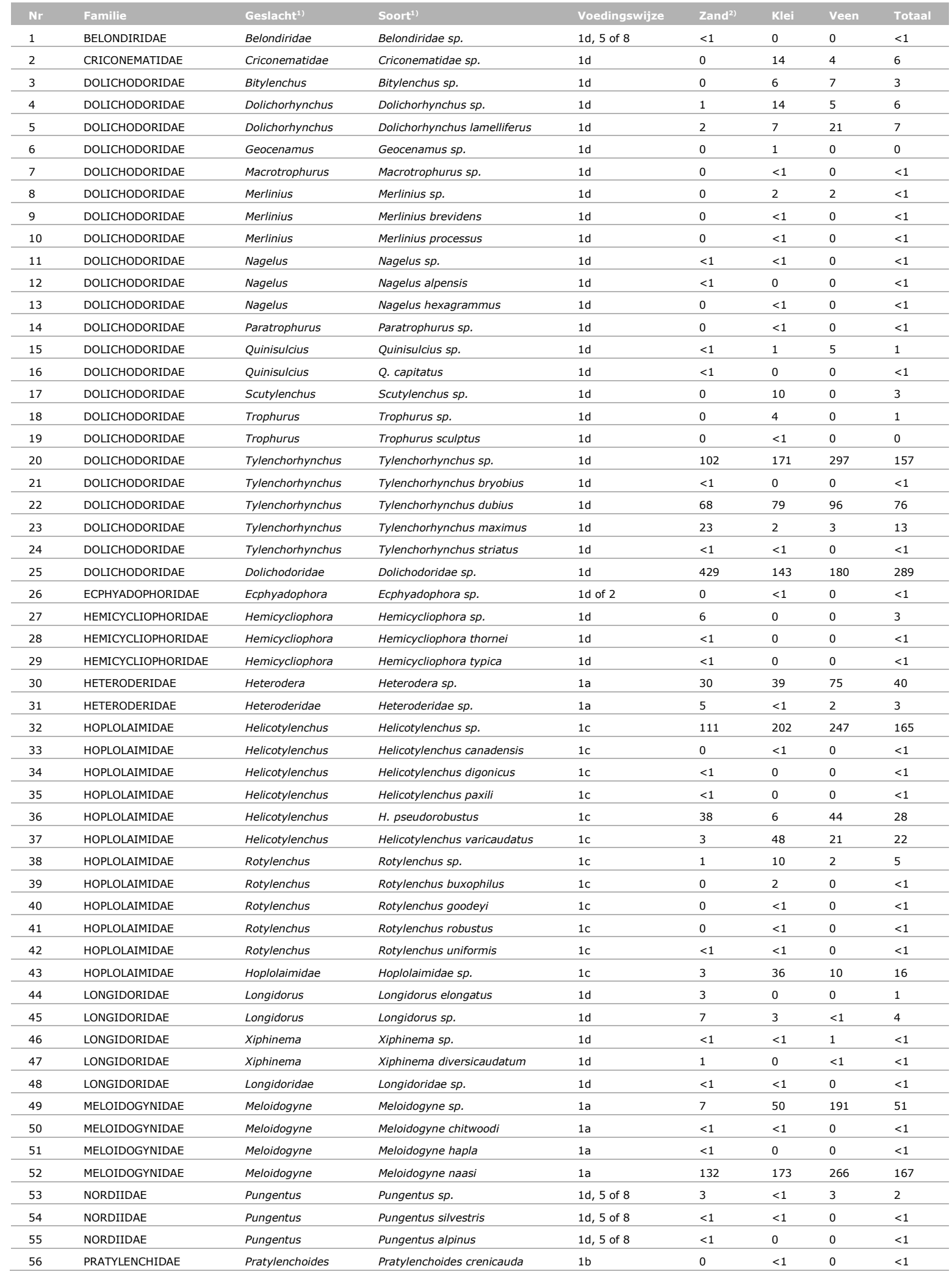




\begin{tabular}{|c|c|c|c|c|c|c|c|c|}
\hline $\mathrm{Nr}$ & Familie & Geslacht $^{11}$ & Soortt) & Voedingswijze & Zand $^{2)}$ & Klei & Veen & Totaal \\
\hline 57 & PRATYLENCHIDAE & Pratylenchus & Pratylenchus sp. & $1 \mathrm{~b}$ & 106 & 231 & 292 & 179 \\
\hline 59 & PRATYLENCHIDAE & Pratylenchus & Pratylenchus fallax & $1 \mathrm{~b}$ & 0 & $<1$ & $<1$ & $<1$ \\
\hline 60 & PRATYLENCHIDAE & Pratylenchus & Pratylenchus neglectus & $1 \mathrm{~b}$ & $<1$ & 2 & $<1$ & 1 \\
\hline 61 & PRATYLENCHIDAE & Pratylenchus & Pratylenchus penetrans & $1 \mathrm{~b}$ & 5 & 15 & 12 & 10 \\
\hline 63 & PRATYLENCHIDAE & Pratylenchus & Pratylenchus thornei & $1 \mathrm{~b}$ & $<1$ & 4 & 0 & 2 \\
\hline 64 & PRATYLENCHIDAE & Pratylenchus & Pratylenchus vulnus & $1 \mathrm{~b}$ & $<1$ & 0 & 0 & $<1$ \\
\hline 65 & PRATYLENCHIDAE & Pratylenchidae & Pratylenchidae sp. & $1 \mathrm{~b}$ & $<1$ & 2 & 29 & 6 \\
\hline 66 & TRICHODORIDAE & Paratrichodorus & Paratrichodorus sp. & $1 d$ & 3 & $<1$ & 0 & 2 \\
\hline 67 & TRICHODORIDAE & Paratrichodorus & Paratrichodorus pachydermus & $1 d$ & $<1$ & 0 & 0 & $<1$ \\
\hline 72 & TRICHODORIDAE & Trichodoridae & Trichodoridae sp. & $1 d$ & 13 & $<1$ & 0 & 6 \\
\hline 73 & TYLENCHIDAE & Aglenchus & Aglenchus sp. & $1 \mathrm{e}$ & 2 & $<1$ & $<1$ & 1 \\
\hline 74 & TYLENCHIDAE & Aglenchus & Aglenchus agricola & $1 \mathrm{e}$ & 53 & 38 & 43 & 46 \\
\hline 75 & TYLENCHIDAE & Boleodorus & Boleodorus sp. & $1 \mathrm{e}$ & 0 & $<1$ & 0 & $<1$ \\
\hline 76 & TYLENCHIDAE & Boleodorus & Boleodorus thylactus & $1 \mathrm{e}$ & 0 & 8 & 0 & 3 \\
\hline 77 & TYLENCHIDAE & Cephalenchus & Cephalenchus sp. & $1 \mathrm{e}$ & $<1$ & 0 & 0 & $<1$ \\
\hline 78 & TYLENCHIDAE & Coslenchus & Coslenchus sp. & $1 \mathrm{e}$ & 9 & 6 & 4 & 7 \\
\hline 79 & TYLENCHIDAE & Coslenchus & Coslenchus costatus & $1 \mathrm{e}$ & 2 & $<1$ & $<1$ & 1 \\
\hline 80 & TYLENCHIDAE & Coslenchus & Coslenchus rhombus & $1 \mathrm{e}$ & $<1$ & 0 & 0 & $<1$ \\
\hline 81 & TYLENCHIDAE & Filenchus & Filenchus sp. & $1 \mathrm{e}$ & 29 & 159 & 184 & 99 \\
\hline 88 & TYLENCHIDAE & Malenchus & Malenchus bryophilus & $1 \mathrm{e}$ & 0 & 0 & $<1$ & $<1$ \\
\hline 89 & TYLENCHIDAE & Neopsilenchus & Neopsilenchus sp. & $1 \mathrm{e}$ & $<1$ & $<1$ & 0 & $<1$ \\
\hline 90 & TYLENCHIDAE & Psilenchus & Psilenchus sp. & $1 \mathrm{e}$ & 1 & 29 & 12 & 13 \\
\hline 91 & TYLENCHIDAE & Psilenchus & Psilenchus hilarulus & $1 \mathrm{e}$ & $<1$ & 2 & 0 & 1 \\
\hline 92 & TYLENCHIDAE & Tylenchus & Tylenchus sp. & $1 \mathrm{e}$ & 0 & 9 & 2 & 3 \\
\hline 93 & TYLENCHIDAE & Tylenchus & Tylenchus arcuatus & $1 \mathrm{e}$ & $<1$ & 1 & 0 & $<1$ \\
\hline 94 & TYLENCHIDAE & Tylenchus & Tylenchus elegans & $1 \mathrm{e}$ & 0 & $<1$ & 0 & $<1$ \\
\hline 95 & TYLENCHIDAE & Tylenchidae & Tylenchidae sp. & $1 e$ & 469 & 843 & 844 & 659 \\
\hline 96 & TYLENCHULIDAE & Gracilacus & Gracilacus sp. & $1 d$ & 0 & $<1$ & 0 & $<1$ \\
\hline 97 & TYLENCHULIDAE & Gracilacus & Gracilacus goodeyi & $1 d$ & 0 & $<1$ & 0 & $<1$ \\
\hline 98 & TYLENCHULIDAE & Paratylenchus & Paratylenchus sp. & $1 d$ & 219 & 143 & 279 & 202 \\
\hline 99 & TYLENCHULIDAE & Paratylenchus & Paratylenchus bukowinensis & $1 \mathrm{~d}$ & 0 & $<1$ & 0 & $<1$ \\
\hline 100 & TYLENCHULIDAE & Paratylenchus & Paratylenchus hamatus & $1 d$ & $<1$ & 0 & 0 & $<1$ \\
\hline 101 & TYLENCHULIDAE & Paratylenchus & Paratylenchus microdorus & $1 d$ & 0 & 1 & 5 & 1 \\
\hline 102 & TYLENCHULIDAE & Paratylenchus & Paratylenchus nanus & $1 \mathrm{~d}$ & 21 & 30 & 62 & 31 \\
\hline 103 & TYLENCHULIDAE & Paratylenchus & P. neoamblycephalus & $1 d$ & $<1$ & $<1$ & 0 & $<1$ \\
\hline 104 & TYLENCHULIDAE & Paratylenchus & Paratylenchus projectus & $1 d$ & 23 & 39 & 141 & 47 \\
\hline 105 & TYLENCHULIDAE & Paratylenchus & Paratylenchus similis & $1 d$ & $<1$ & 1 & 0 & $<1$ \\
\hline 106 & TYLENCHULIDAE & Tylenchulidae & Tylenchulidae sp. & $1 d$ & 0 & 1 & 0 & $<1$ \\
\hline
\end{tabular}

1) Wanneer nematoden niet op geslacht (en soort) gedetermineerd konden worden is de familienaam gegeven, met bij 'soort' de toevoeging 'sp.' Als wel op geslacht maar niet op soort gedetermineerd kon worden, is de geslachtsnaam gegeven met toevoeging 'sp.'

2) Aantal monsters: $n=205$ voor zand, $n=147$ voor klei, $n=65$ voor veen, en $n=417$ in totaal 

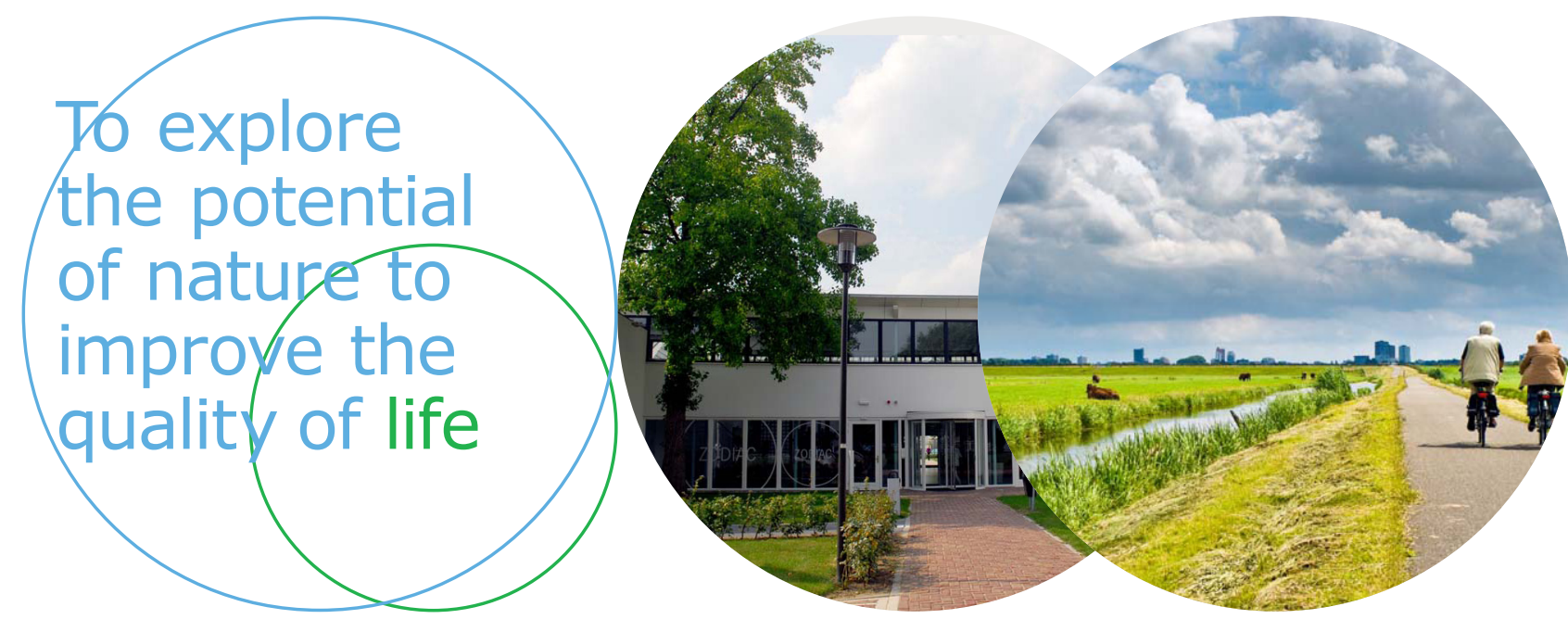

Wageningen Livestock Research Postbus 338

Wageningen Livestock Research ontwikkelt kennis voor een zorgvuldige en $6700 \mathrm{AH}$ Wageningen

T 0317483953

E info.livestockresearch@wur.nl www.wur.nl/ livestock-research renderende veehouderij, vertaalt deze naar praktijkgerichte oplossingen en innovaties, en zorgt voor doorstroming van deze kennis. Onze wetenschappelijke kennis op het gebied van veehouderijsystemen en van voeding, genetica, welzijn en milieu-impact van landbouwhuisdieren integreren we, samen met onze klanten, tot veehouderijconcepten voor de $21 \mathrm{e}$ eeuw.

De missie van Wageningen University \& Research is 'To explore the potential of nature to improve the quality of life'. Binnen Wageningen University \& Research bundelen 9 gespecialiseerde onderzoeksinstituten van Stichting Wageningen Research en Wageningen University hun krachten om bij te dragen aan de oplossing van belangrijke vragen in het domein van gezonde voeding en leefomgeving. Met ongeveer 30 vestigingen, 6.500 medewerkers en 10.000 studenten behoort Wageningen University \& Research wereldwijd tot de aansprekende kennisinstellingen binnen haar domein. De integrale benadering van de vraagstukken en de samenwerking tussen verschillende disciplines vormen het hart van de unieke Wageningen aanpak. 